\title{
Palaeoenvironmental reconstruction of the Milna Valley on the Island of Vis (Central Adriatic) during the late Holocene
}

Faivre, Sanja ${ }^{1}$; Galović, Lidija ${ }^{2}$; Sümegi Pál ${ }^{3}$; Cvitanović, Marin ${ }^{4}$; Náfrádi Katalin ${ }^{3} ;$ Horvatinčić, Nada $^{5}$

${ }^{1}$ University of Zagreb, Faculty of Science, Department of Geography, Marulicev trg 19, 10000 Zagreb, Croatia ${ }^{2}$ Croatian Geological Survey, Sachsova 2, 10000 Zagreb, Croatia

${ }^{3}$ Department of Geology and Palaeontology, University of Szeged, H-6722 Szeged, Egyetem utca 2-6, Hungary

${ }^{4}$ Department of Life and Environmental Sciences, Bournemouth University, Poole, Dorset BH12 5BB, UK

${ }^{5}$ Radiocarbon Laboratory, Ruđer Bošković Institute, Bijenička 54, 10000 Zagreb, Croatia

\section{ABSTRACT}

This study provides a reconstruction of the $1.5 \mathrm{ka}$ palaeoenvironmental evolution of the small, and presently dry, Milna valley on the island of Vis. Sediments from the valley were studied using multi-proxy approach, applying sedimentological, mineralogical, petrological, anthracological, malacological, ${ }^{14} \mathrm{C}$ and land cover analyses, in regard to climatic, vegetation, and hydrological changes.

The mineral composition of the siliciclastic detritus from the Milna valley points to the Dinaride Ophiolite Zone in Bosnia as its dominant source of origin, eroded by the Neretva River, and deposited in the form of alluvial sediments in the Central Adriatic area. However, Cetina and Drin Rivers may have also contributed some of the sediments. Regional aeolian resedimentation of the material occurred during Pleistocene, which later accumulated and became preserved in the Milna valley. Beside the Dinaride Ophiolite Zone, part of the mineral composition is influenced by minerals from the Alpine region and by neutral to basic volcanism, probably of Italian origin.

During the Dark Age Cold Period (DACP) the Milna valley was covered by forests of the Pinus sylvestris group, within which cold-resistant and closed forest habitat preferring species (molluscs) lived. This forested environment probably lasted until the Little Ice Age (LIA) period when fires occurred in the $15^{\text {th }}$ and $16^{\text {th }}$ centuries. The opening of the landscape corresponded to the resettling of the population from the interior to the coast and to the expansion of vineyards on the island. The deforestation enabled the formation of torrential flows and deposition of unsorted sediments. Most of the pebbles are rounded clasts of the Middle Cretaceous (Cenomanian) dolomite in which the valley is formed. However, pebbles which are not present in outcrops of the Milna valley have also been identified. After the LIA, the valley became dry again and has been continuously under anthropogenic impact ever since. Different cartographic sources enable the further tracing of land cover changes from the beginning of the $19^{\text {th }}$ century to present day. The analysis revealed that the highest anthropogenic impact on the landscape occurred in the second part of the $19^{\text {th }}$ century, after which afforestation started. Moreover, the major issue today relates to changes influenced by the current relative sea level rise. This study adds to the knowledge on coastal fluviokarst valley evolution in typical Mediterranean conditions, relating our understanding of Holocene deposition, human activity, and land cover changes on the island of Vis. 
Keywords: dry valleys; torrent flow; modal analysis; land cover changes; fires, climate change.

\section{Introduction}

In non-carbonate rocks, the agents of erosion dissect the surface into a complex network of valleys, while in carbonate rocks the drainage system relates primarily to underground conduits, so valleys in karst are felt to be foreign forms (Bahtijarević and Faivre, 2016). But, among karst valleys, dry valleys represent one of the most common forms, which are particularly frequent along the eastern Adriatic coast. Certainly, they can be formed only by surface waters (horizontal surface flows) (Bögli, 1980), so karst valleys, as well as other classical valleys, are formed by fluvial processes. Accordingly, dry valleys have been formed by flows that no longer exist today. They are not active and their creation must therefore date back to an earlier period. Most temperate catchments reflect the geomorphic impact of Pleistocene cold stages (Briggs et al., 1997). It is clear that high discharge during previous different climate conditions eroded and enlarged such valleys. Karstic regions with mixed karstic and fluvial characteristics are usually distinguished as fluviokarstic areas (White, 1988; Phillips, 2017).

On the island of Vis, these valleys are (today) dry. In total, there are 37 dry valleys, distributed along the coast and in the interior (Krklec et al., 2012). The morphology of karst valleys relates to many factors: structural; lithological; and climate properties-all of which define their evolution.

During the colder and more humid phases of the Pleistocene, surface drainage played a major role in formation of valleys along the eastern Adriatic coast (Šegota, 1966). In the Dinarides, the Pleistocene was characterised by a cold climate, as indicated by numerous glacial morphological features up to 900 m a.s.l. (Faivre, 1991; Bognar et al., 1991; Bognar and Faivre 2006; Velić et al., 2011; Bočić et al., 2012; Žebre and Stepišnik, 2016). During the Würm Glacial Maximum the average annual temperature was 10 to $12^{\circ} \mathrm{C}$ lower than that of present day, with abundant rainfall (Šegota, 1966; Faivre, 1991; Bognar et al., 1991). The total average precipitation on Velebit Mt. was approximated to 4,662 mm (Faivre, 1991; Bognar et al., 1991), which was enough to create large snow accumulations and regional glaciations with estimated ice thickness of around $200 \mathrm{~m}$ (Bognar et al., 1991). At the same time, the islands of the Kvarner area, such as Krk and Rab, were characterised by periglacial conditions (Ambert and Nicod, 1986). Accordingly, during the Pleistocene, the studied area was also affected by a generally cold climate as evidenced on the nearby island of Hvar by Alpine interstadial and stadial mammal associations, probably belonging to the Würm (Malez, 1972; MarkovićMarjanović, 1976). Thus, surface drainage was important along the eastern Adriatic coast during the Pleistocene, causing intense erosion processes, particularly during periods of snow melting which additionally favoured the activation of fluvial processes. 
Moreover, recent morphology of coastal dry valleys also strongly relates to past sea-level changes, as the global erosional base level during the Pleistocene was lower than today. During the Last Glacial Maximum (LGM), conventionally 21 ka before present (BP), the sea level was at its lowest; it was - $121 \pm 5 \mathrm{~m}$ below present sea level (Fairbanks, 1989). Thus, a significant part of the Adriatic Sea area was dry land (Surić et al., 2009, Surić and Juračić, 2010; Mikulčić Pavlaković et al., 2011; Pavelić et al., 2014; Babić et al., 2013). Therefore, the low sea level during the last glacial period and humid climate conditions supported active fluvial processes (Tzedakis, 2009). During that period, valleys were much longer than they are today. Consequently, during the Late Pleistocene, today's short valleys represented the upper parts of the drainage system with dominant vertical erosion. So, their current morphological properties relate to this earlier period during which their morphogenesis was intense. At the same time, this explains the discrepancy between recent morphology of the coastal valleys and the current erosional base level, as after the rapid Late Pleistocene-Holocene sea level rise erosional processes were strongly reduced. Consequently, current morphological properties of most of the coastal valleys are not concordant with the current erosional base level.

Today, coasts are key geographic areas because they lie at the interface of climate change (Kaniewski et al., 2016). They respond rapidly to environmental changes in human time scales: in years and decades. Moreover, coastal zones represent areas where natural and human activities intervened and are, therefore, particularly interesting for interdisciplinary research (Rajčić et al., 2010; Faivre et al., 2011; Faivre and Mićunović, 2017).

In studying the relative sea level change and climate change on Vis during the last 2,000 years (Faivre et al., 2010; Faivre et al., 2013), the impact of the recent sea-level rise was observed in Milna cove. Due to the significant influence of the sea on nearby vineyards, a new larger stone wall was made to protect the land and vineyards from backward erosion. Accordingly, during April and May in 2009 the valley profile was opened and it became possible to engage in palaeoenvironmental reconstruction of the youngest evolutionary phase of this small dry valley situated on the southern coast of the island (Fig. 1).

Fig. 1.

Due to important geographic position of Vis within the Central Adriatic, the island was settled around 3000 BC (Peričić, 1999). During antiquity it was colonised by the Greeks (the colony of Issa) and subsequently by the Romans (Novak, 1961). Thanks to favourable soil and climate characteristics, Vis has a rich agricultural tradition (Zaninović, 1997) that goes back to ancient times. Karst poljes and valleys have been used for viticulture throughout the ages, which was the most important economic sector on Vis Island (Novak, 1961) - one that is expanding again today. 
This long interaction between man and karst has led to important changes of land cover (and landscape) through the centuries. The term karst itself derives from the impact of early forest clearance and farming on rugged limestone terrain in the northern Dinaric coastal region (Ford and Williams, 2007). Significant human impacts on ecosystems of the eastern Adriatic coast began already around 5000 years ago (Kaniewski et al., 2018). The process of transformation of the originally wooded but stony regions into farmland continued throughout the classical Greek times (Gams, 1991). Deforestation intensified after the $17^{\text {th }}$ century (Fürst-Bjeliš et al., 2001; Fürst-Bjeliš and Lozić, 2006) while clearing in mountain areas was carried out later, in the $18^{\text {th }}$ and $19^{\text {th }}$ centuries, by burning the land and managing the karstic environment (Ballut and Faivre, 2012). This had a direct influence on the type of settlements and on the particular agrarian structure of the area (Nicod, 2003). Likewise, numerous modifications of the topographical surface occurred on Vis, like clearing out stones and creating stony piles in parcels or by creating terraces for cultivation. Therefore the natural and anthropogenic influences are closely related on the island as well as in the Milna valley. Consequently, this study combines sedimentological, mineralogical, geochronological (based on ${ }^{14} \mathrm{C} \mathrm{AMS}$ dating), climatological, morphological and vegetation properties, in order to trace the $1.5 \mathrm{ka}$ evolution of the Milna valley and thus provide information about environmental changes and anthropological influences in the Mediterranean region. By combining the analyses of different aspects it is possible to reconstruct some phases and aspects of the natural development of the area and human impact on landscape and vegetation, as well as distinguishing human impact from other drivers of change-which is not always a straightforward task.

\section{Study area - geological and geomorphologic settings}

The Island of Vis belongs to the Central Dalmatian Islands group. Located $45 \mathrm{~km}$ from the mainland, and with an area of $89.72 \mathrm{~km}^{2}$ (17 km length $\times 8 \mathrm{~km}$ width), it is the $9^{\text {th }}$ largest island in the Adriatic (Duplančić Leder et al., 2004). Vis is characterised by a typically Mediterranean climate (Csa-Hot-summer Mediterranean climate in Köppen's classification) (Zaninović et al., 2008), with a mean annual temperature of $17^{\circ} \mathrm{C}$ (DHMZ) and noticeable seasonal contrasts in precipitation. Average yearly rainfall for the period 1981 - 2009 (Krklec et al., 2012) amounted to $712 \mathrm{~mm}$, concentrated during the cold period of the year, whereas extreme droughts were present during summer.

The Island of Vis is mainly ENE-WSW oriented and thus deviates from the classic Dinaridic NWSE orientation. On the western part of Vis, elevation exceeds 500 meters with the highest peak of Hum at $587 \mathrm{~m}$ a.s.l. while the eastern part of the island does not exceed $300 \mathrm{~m}$ a.s.l. The relief of the Island can be simply described through three main hilly ranges, between which dry valleys and poljes are situated. They are defined by the spreading of main geological structures. The topographic ridges are formed in Cretaceous carbonates and are separated by dry valleys filled with Quaternary deposits. One of such fluviokarstic form is the Milna valley. 
It is situated on the southern coast of the island and spreads in the NE-SW direction following the Stupišće - Milna fault zone (Korbar et al., 2012) (Figs. 1 and 2).

Structurally, the island represents an anticline that spreads roughly east-west and sinks $10^{\circ}$ on average toward the east (Korbar et al., 2012). The core of the anticline is made up of clastites with gypsum and igneous rocks, while the limbs are of Cretaceous carbonate limestone and dolomites accumulated on the ancient Adriatic Carbonate Platform (Vlahović et al., 2002, 2005). In the depths below the Lower Cretaceous on the larger area of Vis anhydrites can be found. The westernmost part of the island consists of magmatic and clastic rocks associated with the Komiža bay diapir (Crnolatac, 1953; Šušnjar, 1967; Grandić et al., 1997, 2010; Belak et al., 2005; Korbar, 2009; Korbar et al. 2009; Babić et al., 2012).

\section{Fig. 2}

The anticline is completely cut by faults parallel with the hinge line of the anticline. The transversal orientation of the regional stress direction, which is oriented nearly $\mathrm{N}-\mathrm{S}$ and varies between $15-195^{\circ}$ and $340-160^{\circ}$ (Pribičević et al., 2001; Prelogović et al 2004; Palenik, 2005) in relation to the spreading of structures, points to the compressional character of the structures and to the locally-expressed left horizontal movement.

The youngest sedimentary complex is represented by Quaternary deposits that cover a large part of the island. They developed in several continental facies: terra rossa; breccia; brecciaconglomerates; and aeolian sands. They are primarily remains from the past glacial periodslargely Pleistocene. The seven youngest sedimentary phases were identified on Vis by Marković-Marjanović (1977). The oldest sequence is represented by the redistributed terra rossa, the genesis of which is probably related to the Mindel - Riss period. The thickest deposits of terra rossa are found in the karst poljes. The core drilled in Velo Polje shows that the thickness of Quaternary sediments, in general, runs up to $45 \mathrm{~m}$ (Crnolatac, 1954). During the cold climate of the Riss period the creation of talus deposits ensued (second phase), which are consolidated today in breccias forming scree cones. They were relatively dated in the Milna valley and Pothumlje area (Marković-Marjanović, 1977). The third phase is characterised by the conglomerates of fluvial origin and breccia-conglomerates found in Komiža bay from the Riss and Würm interglacial. Subsequently, the sedimentation of aeolian sands occurred (up to $10 \mathrm{~m}$ thick) during the Würm period (the fourth phase, Würm I), e.g. in Malo Zlopolje, Velo Zlo polje, Borovo polje, Tihobraće polje, etc. As aeolian sands were transported from the NE sector area- which is below the sea-level today (MarkovićMarjanović, 1977)-only the NE-SW oriented poljes have sand deposits (Fig. 2). The presence of fossil remains of Pupa muscorum gastropods (Milojević, 1927) confirms its Pleistocene, continental, and aeolian origin. During the fifth phase, brown soil (palaeosol) was created, upon which sand deposits from the sixth phase accumulated at Zlopolje. The last (seventh) phase of the climate change is documented with the creation of post-Pleistocene brown soils (Marković-Marjanović, 1977) that are still forming today. On the nearby island of Korčula, this soil is described as Arenosols according to the World Reference Base (FAO/ISRIC/ISSS, 2006), 
and the mineral and geochemical composition of the bedrock indicated the polygenetic origin of sand deposits (aeolian and fluvial) (Romić et al., 2014).

Pleistocene aeolian deposits occur in many places along the eastern Adriatic coast as patchlike cover over Mesozoic deposits. Their actual location is principally influenced by the type of karst depressions (landforms) which represented traps for sediments (Babić et al., 2013) during the time of their accumulation. Closed karst depressions represent better traps for accumulation and preservation of aeolian sands while more opened karstic forms are characterised by a partial removal of sands down-valley (Babić et al., 2013). Two such elongated opened karst depressions covered with sand can be distinguished on Vis: Milna and Stončica valleys. These two depressions are open to the sea at their NE ends which suggests that besides the main impact of tectonic fracturing, their formation may have also been influenced by fluvial erosion which preceded the deposition of Pleistocene sands (Babić et al., 2013). Consequently they can be considered fluviokarstic valleys.

Typical karst features represented on the Vis Island today are poljes, uvalas and dry valleys whose formation and position were strongly predisposed by structural properties of the area. Faults on Vis are mainly sub-parallel to the longer axis of the island (Palenik, 2005). Within the structural-tectonic unit of Milna, Palenik (2005) noticed the presence of fewer local NE-SW faults, e.g. parallel to the main boundary faults. Likewise, the Milna valley has been formed along the Stupišće - Milna cove fault zone (Fig. 2). Around the edges of the valley talus breccias are widespread. The Milna valley is characterised by a particular morphology. It represents a small opened geomorphic system, i.e. a beheaded valley (without headwater source area) probably testifying to past structural influences and its long morphological evolution. The valley is up to $2 \mathrm{~km}$ long. It is of very low slope and with only $70 \mathrm{~m}$ of denivelation (Fig. 3). Several processes therefore, including deformation, karstification and fluvial erosion influenced the origin and shape of the Milna valley.

Fig. 3.

\section{Methods}

\subsection{Field work}

Field work comprised sedimentological and geomorphologic analyses of the site. The field work analyses and sampling were performed in spring 2009 on a profile that was exposed and approachable only during reconstruction of the supporting wall. The profile was $5 \mathrm{~m}$ from the shoreline. The two metres at the top of the profile were accessible for sampling. This investigation was focused on a layer composed of charcoal and pebble beds (between 70 and $100 \mathrm{~cm}$ below the surface) pointing to possible environmental change. Because of lateral alteration, i.e. thinning or fading, charcoal and/or pebble beds are not continuous. However, if present, charcoal overlays the pebble bed. Sampling was performed on three sections where 
four samples were taken (Milna 1 - Milna 4; later in the text addressed as sample 1 - 4). The sections were distributed along exposed part of profile (from the central to the southern side of the valley profile).

Top $70 \mathrm{~cm}$ of the profile was not sampled, because of pedogenesis and agricultural activity in the valley and the most probable modern plugging on location (Fig. 1). Contacts with upper and lower layers were described. Colours of the samples were determined on wet sediment by reference to the Munsell Soil Colour Charts (Munsell, 2013). A grain-size composition of $>2$ $\mathrm{mm}$ fraction was determined in the field in order to avoid the transportation of large amounts of gravel material to the laboratory. At least 100 particles per sample from a homogeneous area of the streambed were randomly collected and measured (Switzer, 2013). Roundness, grading, and sorting of coarse-grained sediments were visually estimated.

Fig. 4.

\subsection{Modal analyses and petrographic microscopy of pebbles}

Modal analyses and petrographic microscopy of pebbles were carried out at the Croatian Geological Survey. Modal analyses of four samples were performed in the $0.09-0.16 \mathrm{~mm}$ carbonate-free fraction. Heavy and light mineral fractions (HMF and LMF) were separated by bromoform liquid $\left(\delta\left(\mathrm{CHBr}_{3}\right)=2.85-2.88 \mathrm{~g} \mathrm{~cm}^{-3}\right)$. Qualitative and quantitative analyses of $\mathrm{HMF}$ and LMF were performed by identifying $300-400$ grains per thin section using polarising light microscope (Mange and Maurer 1992, Durn et al., 2007). Thin sections were prepared from lithic detritus. They were used to investigate their mineral composition in order to detect a possible source material of sediment.

Based on weathering index (W.I.), a degree of alteration of analysed horizons was examined. Weathering index was defined by Brewer (1976) as a ratio of percentages of resistant and not resistant minerals: $\mathrm{W} . \mathrm{I} . \mathrm{l}=(\mathrm{zr}+\mathrm{tu}+\mathrm{ru}+\mathrm{ti}+\mathrm{st}+\mathrm{g}) /(\mathrm{ep}-\mathrm{zt}+\mathrm{am}+\mathrm{py}+\mathrm{cy})$. It is calculated based on four decimal places of content percentages of analysed minerals.

Higher W.I. indicates significant or repeated weathering of analysed grains, as a consequence of long exposure to warm humid geochemical environment and/or resedimentation.

Thin sections were prepared from pebbles, $3-5 \mathrm{~cm}$ in diameter, incorporated in analysed layer. Three pebbles (a, b, and c) were analysed from each sample (1, 2, 3 and 4), so 12 thin sections of pebbles were analysed. They were used to investigate the origin of deposited material.

3.3. Grain-size, chemical, malacological, anthracological and geochronological- ${ }^{14} \mathrm{C}$ analyses 
Grain-size of $<2 \mathrm{~mm}$ fraction, chemical, malacological and anthracological analyses were performed at the Department of Geology and Palaeontology, University of Szeged in Hungary. For grain-size and chemical analyses samples have been previously air-dried and sieved (samples $<2 \mathrm{~mm}$ ).

The grain-size composition of $>2 \mathrm{~mm}$ fraction was determined in the field while the grain-size composition of $<2 \mathrm{~mm}$ fraction (matrix) was carried out using the laser-sedigraph method. Samples were pre-treated with $1 \mathrm{M} \mathrm{HCl}$ and $\mathrm{H}_{2} \mathrm{O}_{2}$ to remove $\mathrm{CaCO}_{3}$ and organic matter respectively. For a more detailed description of the pre-treatment process, see Konert and Vandenberghe (1997). All the samples were measured for 42 intervals between 0.0001 and $0.5 \mathrm{~mm}$ using an Easy Laser Particle Sizer 2.0 and Fritsch sieves (Buurman et al., 1997) in Szeged (Hungary).

The sequential extraction method was used for geochemical analyses of bulk sediment samples (Dániel, 2004), with a long established history in the analysis of geochemical composition of lacustrine sediments. From the full procedure the step of water extraction for unseparated samples was sufficient to suit our analytical needs as it was shown by previous works (Dániel, 2004, Sümegi et al., 2013). The water-soluble element contents show close relationship with weathering processes, since water-soluble elements in the terrestrial sediment usually derived from weathering processes (Dániel, 2004). Consequently, sequential extraction method results could be a good indicator of palaeohydrological and palaeoecological environment.

Distilled water was purified using a Millipore fife 5 Plus Water Purification System for water extraction samples. $100 \mathrm{ml}$ distilled and purified water was added to $1.0 \mathrm{~g}$ sample and shaken for 1 hour, and then the water extract elements of $\mathrm{Na}, \mathrm{K}, \mathrm{Ca}, \mathrm{Mg}$, Fe were analysed using a Perkin-Elmer AAS spectrometer (Dániel, 2004).

Malacological analyses of gastropod and mollusc shells revealed environmental conditions that existed at the time of sedimentation while anthracological analyses of charcoal from the sediments enabled identification of charcoal based on wood anatomy, revealing former vegetation of the area. Charcoals were identified using polarisation microscope with 100x, 200x, and 500x magnifications. The taxon identification was carried out using reference books by Greguss $(1945,1972)$ and Schweingruber (1990).

The chronostratigraphy of sediments was determined using six radiocarbon dates undertaken on molluscs and charcoal samples (from samples 1 and 4). The chronology is based on ${ }^{14} \mathrm{C}$ techniques for dating using accelerator mass spectrometry (AMS) using graphite sample preparation in the Radiocarbon Laboratory in Zagreb (Krajcar Bronić et al., 2010) and ${ }^{14} \mathrm{C}$ measurement of graphite targets on AMS at the University of Georgia, Center for Applied Isotope Studies, USA. The results were reported as relative specific activity of ${ }^{14} \mathrm{C}(14 \mathrm{a})$ in percentage of modern carbon (pMC), which relates the ${ }^{14} \mathrm{C}$ content of a sample to the ${ }^{14} \mathrm{C}$ content of a modern standard normalised for isotope fractionation. The ${ }^{14} \mathrm{C}$ age was expressed 
in conventional ${ }^{14} \mathrm{C}$ years BP. ${ }^{14} \mathrm{C}$ ages were subsequently calibrated using the OxCal Software (using IntCal 13 and Marine 13 curves).

\subsection{Impact of the actual sea level rise on the Milna beach}

The beach was considered vulnerable to sea level rise, so we monitored it for three years. The change in the beach size (1968 - 2011) was estimated by comparison of the topographic map from 1976 and in situ measurements in 2009, 2010 and 2011. Recent measurements have been averaged and the difference between the 1976 and 2009 - 2011 calculated in order to assess the impact of the relative sea-level rise to the beach today.

\subsection{Land cover changes}

The data for the land cover change analysis since the $19^{\text {th }}$ century in the Milna area were obtained from georeferenced cadastral maps of the Franciscan cadastre (1834) and georeferenced ortho-photos from 1968 and 2009 acquired from the Ministry of Construction and Physical Planning and the State Geodetic Administration of the Republic of Croatia respectively. The maps and ortho-photos were manually digitised and a map overlay method was applied to discover the trends in land cover change in the studied area for the three main phases (cartographically documented years). This research focused on two types of land cover: forest (including degraded forest and maquis) and arable land. The categories of artificial surfaces (built-up land), bare rocks and sparsely vegetated areas were not included. All of the analyses were conducted using ArcMap 10.1. Additional results for the most recent period were acquired from the CORINE land cover database 1980 - 2012.

\section{Results}

\subsection{Field work analyses}

Three main laterally-extending horizons were noticed along the profile (Fig. 4). The lowest accessible meter of the whole profile is composed of structureless reddish brown (Munsell, 2013) clayey silt with rare carbonate well rounded pebbles up to $5 \mathrm{~cm}$ in diameter. Inclination of pebbles was not noticed. Fe/Mn-concretions are equally dispersed along the whole horizon and they are up to $3 \mathrm{~mm}$ in diameter. Thickness of the layer remains unknown because the content with underlying rock was not reached.

The focus of this investigation was a layer of carbonate clast-supported gravel covered with up to $5 \mathrm{~cm}$ of charcoal, found between 70 and $100 \mathrm{~cm}$ below the surface. In the central part of the valley (sample 4), the gravel bed is the thickest, reaching $25 \mathrm{~cm}$, and it thins laterally (15 cm in sample 2) and in the marginal part of the valley disappears, while charcoal extends laterally as a $3 \mathrm{~cm}$ thick bed. The charcoal grains are up to $3 \mathrm{~cm}$ long, fossiliferous (containing gastropod shells), and are distributed along the whole profile. The gravel bed is composed of 
unsorted, ungraded, sub-rounded pebbles, $2 \mathrm{~mm}-10$ (15) $\mathrm{cm}$ in diameter, intercalated in silty clay. The matrix has the same structure, texture, composition and colour as underlying clayey silt. The long axes of the clasts are inclined to the bedding plane. This sediment body has the form of a channel parallel to the elongation of the valley. The channel is incised in the underlying silty clay with a strong erosional boundary. The clasts are AB-plane imbricated, where the intermediate clast axes are oriented in the flow direction and the longest axes are perpendicular to the flow to the $\mathrm{E}$ (approximately 270/20).

Charcoal bed has a sharp clear border with overlaying sediment which is represented with reddish brown (Munsell, 2013) structureless clayey silt, which was not analysed because of obvious modern human activity and pedogenesis.

Table 1 Sampling locations and field observations

\begin{tabular}{|c|c|c|l|}
\hline Sample ID & $\begin{array}{c}\text { Gauss-Krüger } \\
\text { coordinate system }\end{array}$ & $\begin{array}{c}\text { Depth from } \\
\text { the surface } \\
(\mathbf{c m})\end{array}$ & \multicolumn{1}{|c|}{ Field observation } \\
\hline 1 & $\begin{array}{l}5600635 \\
4766918\end{array}$ & $90-100 \mathrm{~cm}$ & $\sim 1$ m north of the fluvial bed (sample 4) \\
\hline 2 & $\begin{array}{l}5600638 \\
4766901\end{array}$ & $70-90 \mathrm{~cm}$ & $\sim 2$ m south of the fluvial bed (sample 4) \\
\hline 3 & $\begin{array}{l}5600638 \\
4766901\end{array}$ & $90-100 \mathrm{~cm}$ & $\sim 2$ m south of the fluvial bed (sample 4) \\
\hline 4 & $\begin{array}{l}5600636 \\
4766904\end{array}$ & $70-100 \mathrm{~cm}$ & $\begin{array}{l}\text { Located where the horizon is the thickest; thick } \\
\text { layer of pebbles-fluvial bed }\end{array}$ \\
\hline
\end{tabular}

\subsection{Modal analyses}

The results of modal analysis of samples indicated the dominance of light mineral fractions (LMF), in comparison with heavy minerals (HMF), which constitute $10-11.3 \%$ (Table 2). The contribution of quartz in LMF ranges between 39 and 52\%. Quartz grains are characterised with strait extinction. Fresh quartz grains (Table 3) are very bright, angular, sometimes hypidiomorphic-idiomorphic with inclusions (Fig. 5a), while weathered quartz grains are most commonly sub-rounded (Fig. 5b), characterised by surface erosion in form of points and/or stripes. Feldspars are mostly colourless and weathered. Weathered K-feldspars occur as monocrystals with zircon and apatite inclusions, while fresh grains are less common, sometimes represented by very bright hypidiomorphic-idiomorphic zoned grains with inclusions (apatite?) (Fig. 5c1 and 2). Polysynthetic plagioclase twins are sporadic. Lithic particles are mainly well-rounded quartzite grains, with some "impurities" of sericite, chlorite, hornblende, biotite, or combinations thereof. If the grains are parts of schistose rocks, they are most frequently fine-grained black shale or green schists (present in all samples). As a part of transparent lithic particles, unmetamorphosed cherts are present in all samples making up around $10 \%$ of LMF (Table 3 ). In the LMF muscovite is rare and exclusively in the form of sericite. 
There is a narrow range of contribution of HMF in the analysed samples and a similar mineral composition (Table 2). The opaque minerals are present in less than $40 \%$, the micaceous minerals biotite and chlorite are infrequent, and the rest are transparent heavy minerals. The most abundant transparent heavy minerals are pyroxenes (32 - 51\%), amphiboles (24 - 44\%) and minerals from epidote-zoisite group (12 - 18\%). Pyroxenes consist of fresh bright elongated grains of orthopyroxenes (mostly hypersthenes with brown-reddish-colourless pleochroism) (Fig. 5e) and clinopyroxenes (mostly represented with diopside-hedenbergite group minerals (Fig. 5d) and a few grains of augite). In samples 1 and 2, clinopyroxenes are dominant (Fig. 5d). Amphiboles are represented by hornblende-type amphiboles. These grains are very fresh, elongated and do not always have the expected pronounced cleavage. Several hypidiomorphic zoned hornblende crystals were found. Pleochroism is conspicuous and mostly dark green-olive green; light green-dark green; brown-green. The epidote-zoisite group is presented with equidimensional, irregular grains. Dominating zoisite is colourless and with a characteristic anomalous blue interference colour, while epidote is usually yellowish to greenish and shows weak pleochroism. Garnet grains are sporadic, pink and have an abraded surface. The weathering index is low in all samples.

Table 2 Modal composition of heavy and light mineral association (0.09-0.16 mm). Legend in Table 3.

\begin{tabular}{|c|c|c|c|c|c|c|c|c|c|c|c|c|c|c|c|c|c|c|c|c|c|c|}
\hline \multirow{2}{*}{ Sample } & \multirow{2}{*}{\begin{tabular}{|c|} 
Depth \\
from the \\
surface \\
(cm)
\end{tabular}} & \multicolumn{4}{|c|}{$\begin{array}{c}\text { Composition of } \\
\text { LMF } 100 \%\end{array}$} & \multirow{2}{*}{$\begin{array}{c}\% \text { HMF } \\
\text { per } \\
\text { sample }\end{array}$} & \multicolumn{4}{|c|}{$\begin{array}{c}\text { Composition of } \\
\text { HMF } 100 \%\end{array}$} & \multicolumn{12}{|c|}{ Transparent heavy minerals $100 \%$} \\
\hline & & q & $f$ & $\mathrm{~m}$ & 1 & & op & co & $\mathrm{b}$ & $\begin{array}{l}\text { tran. } \\
\text { min. }\end{array}$ & \begin{tabular}{|l|} 
ep- \\
-zt \\
\end{tabular} & am & py & $g$ & cy & st & tu & $\mathrm{zr}$ & ru & $\mathrm{ti}$ & ap & $\mathrm{cr}$ \\
\hline 1 & $90-100$ & 44 & 9 & 4 & 43 & 11.30 & 32 & 0 & 2 & 67 & 12 & 24 & 51 & 4 & 0 & 0 & 3 & 2 & 0 & 0 & 0 & 2 \\
\hline 2 & $70-90$ & 45 & 14 & 1 & 40 & 10.00 & 33 & 0 & 1 & 66 & 16 & 30 & 42 & 7 & 0 & 2 & 0 & 1 & 0 & 0 & 0 & 2 \\
\hline 3 & $90-100$ & 39 & 5 & 2 & 54 & 10.76 & 40 & 1 & 3 & 55 & 15 & 44 & 32 & 4 & 0 & 2 & 0 & 0 & 1 & 0 & 0 & 0 \\
\hline 4 & $70-100$ & 52 & 8 & 1 & 39 & 10.47 & 10 & 1 & 2 & 87 & 18 & 35 & 42 & 3 & 0 & 0 & 0 & 0 & 1 & 0 & 0 & 0 \\
\hline
\end{tabular}

Table 3 Modal composition of light mineral fraction (values in \%) and weathering index.

\begin{tabular}{|c|c|c|c|c|c|c|c|c|c|c|c|c|}
\hline \multirow{2}{*}{ Sample } & \multirow{2}{*}{$\begin{array}{l}\text { Depth from } \\
\text { the surface } \\
\text { (cm) }\end{array}$} & \multicolumn{2}{|c|}{ Quartz } & \multirow{2}{*}{ m } & \multicolumn{4}{|c|}{ Feldspar } & \multicolumn{3}{|c|}{ Lithic particles } & \multirow{2}{*}{ W.I. } \\
\hline & & fresh & weathered & & $\begin{array}{r}\text { K-1 } \\
\text { fresh }\end{array}$ & $\begin{array}{l}\text { feldspar } \\
\text { weathered }\end{array}$ & $\begin{array}{r}\text { pla } \\
\text { fresh }\end{array}$ & $\begin{array}{l}\text { gioclase } \\
\text { weathered }\end{array}$ & quartzite & chert & other & \\
\hline 1 & $90-100$ & 18 & 25 & 4 & 3 & 6 & + & 1 & 21 & 11 & 11 & 11.48 \\
\hline 2 & $70-90$ & 24 & 21 & 1 & 5 & 8 & 1 & 0 & 24 & 9 & 7 & 11.30 \\
\hline 3 & $90-100$ & 14 & 24 & 2 & 1 & 4 & 1 & 0 & 19 & 9 & 26 & 8.13 \\
\hline 4 & $70-100$ & 19 & 33 & 1 & 1 & 5 & 1 & + & 14 & 7 & 18 & 5.11 \\
\hline
\end{tabular}

Legend: $q$ - quartz, $\mathrm{f}$ - feldspar, $\mathrm{m}$ - muscovite, $\mathrm{I}$ - transparent lithic particles, op -opâque minerals, ch - chlorite, $b$ - biotite, ep-zt - epidote-zoisite, am - amphibole, py - pyroxene, g garnet, cy - kyanite, st - staurolite, tu - tourmaline, $\mathrm{zr}$ - zircon, ru - rutile, ti - titanite, ap apatite, $\mathrm{cr}$-chromite, +- minerals with occurrence $<0.5 \%$, W.I. $=(z r+t u+r u+t i+s t+g) /(e p-z t+a m+p y+c y)$. 
Fig. 5.

\subsection{Petrographic analyses of pebbles}

The analysed 12 thin sections of pebbles could be grouped in three basic groups: 1) Dolomite; 2) Ferrous carbonate concretion; and 3) Fossiliferous limestone.

1) Fine to coarse grained crystalline dolomite. If the dolomite sample contains cracks, they are partly filled with idiomorphic course-grained crystals of dolomite or completely filled with course-grained alotriomorphic crystals (Fig. 6a). There is no visible siliciclastic detritus. Ten of twelve analysed pebbles are represented by dolomite.

2) Fine-grained siliciclastic detritus cemented by micritic-microsparitic cement, saturated with reddish clay minerals and $\mathrm{Fe} / \mathrm{Mn}$ oxides and hydroxides. $\mathrm{Fe} / \mathrm{Mn}$ oxides and hydroxides are dispersed in the groundmass or concentrated in concretions (Fig. 6b). Grains are mostly quartzite and chert, rarely quartz and K-feldspars, plagioclase, light green-brown amphiboles and epidote. This group_is represented by only one thin section of $2 a$, i.e. ferrous limestone carbonate concretions are sporadically present only in sample 2.

3) Bioaccumulated clastic grainstone-packstone with sparitic cement consisting almost exclusively of Bryozoa and particles of big Foraminifera, and a sporadic assortment of other carbonate fossils and their fragments (Fig. 6c). They are of Neogene age and represented within section $4 a$ as sporadic constituent of sample 4.

Fig. 6.

\subsection{Grain-size and chemical analyses of sediments}

Based on grain-size of $<2 \mathrm{~mm}$ fraction, matrix is represented by clayey silt. The analysis shows the dominance of silt fractions (fine and course-grained silt) with a contribution of $56-79 \%$, and between $0-7 \%$ of sand (Table 4). Sample 1 is characterised by the highest content of clay (43\%), the lowest content of course silt fraction (11.3\%), and an absence of sand fraction, making sample 1 the finest analysed sediment from all sample locations.

Generally, based on obtained data (Table 5), the nutrient content of sediments seems to be favourable for agricultural use. Likewise, the sample 1 shows the higher nutrient content ( $\mathrm{K}$, $\mathrm{Mg}, \mathrm{Na}$, and $\mathrm{Fe}$ ) in the sediments and a low content of $\mathrm{Ca}$. Of course, $\mathrm{Fe}, \mathrm{Na}, \mathrm{K}$ content is higher in the clayey sediments which better retains nutrients. Conversely, sample 4 from the middle of the channel, with the predominance of coarse silts and pebbles, has the lowest content of $\mathrm{Fe}, \mathrm{Na}, \mathrm{K}$ and a highest content of $\mathrm{Ca}$ (Tables 4 and 5). Due to the position of sample 4 (Fig. 4) near the torrent bed, these elements might have been washed away. The clay-rich sediments are well supplied with $\mathrm{Mg}$ (sample 1, Table 5), which attests that $\mathrm{Mg}$ is primarily present in 
clay fractions. The presence of $\mathrm{Ca}$ is higher in the leached sediments (sample 4) and lower in the clayey sediments (sample 1) indicating positive correlation with the course silt fraction.

Table 4 Result of grain-size analyses of $<2 \mathrm{~mm}$ fraction, values in wt\%

\begin{tabular}{|c|c|c|c|c|}
\hline Sample & clay $(<0.002 \mathrm{~mm})$ & fine silt $(0.002-0.02 \mathrm{~mm})$ & course silt $(0.02-0.06 \mathrm{~mm})$ & sand $(>0.06 \mathrm{~mm})$ \\
\hline 1 & 43.2 & 44.5 & 11.3 & 0 \\
\hline 2 & 27.3 & 32.1 & 33.3 & 7.3 \\
\hline 3 & 16.9 & 35.9 & 39.9 & 6.3 \\
\hline 4 & 14.2 & 35.6 & 43.4 & 5.3 \\
\hline
\end{tabular}

Table 5 Results of chemical analysis of water soluble fraction in $\mathrm{mg} / \mathrm{kg}$

\begin{tabular}{|c|c|c|c|c|c|}
\hline Sample & $\mathbf{F e}$ & $\mathbf{N a}$ & $\mathbf{K}$ & $\mathbf{M g}$ & $\mathbf{C a}$ \\
\hline 1 & 1132 & 3422 & 897 & 4678 & 1786 \\
\hline 2 & 765 & 2422 & 497 & 2678 & 5786 \\
\hline 3 & 365 & 722 & 197 & 3699 & 6932 \\
\hline 4 & 198 & 324 & 113 & 3981 & 8765 \\
\hline
\end{tabular}

\subsection{Malacological, anthracological and geochronological analyses}

The identified molluscs (Table 6) revealed that most of the species found (Macrogastra ventricosa, Trichiahispida, Discus ruderatus and Succinea oblonga) were Gastropods that preferred a closed forest habitat, and were cold-resistant terrestrial species. Vallonia costata, found in sample 2-also a terrestrial species, specifically a mesophilous shell-lived in intermediate or moderate environmental conditions without extremes of moisture or dryness; sometimes restricted to conditions of moderate moisture or to moderate temperature.

Table 6 Wood/charcoal and mollusc species determination the samples

\begin{tabular}{|c|c|l|l|}
\hline Sample & $\begin{array}{c}\text { Number of } \\
\text { charcoal } \\
\text { fragments }\end{array}$ & Charcoal/wood species & \multicolumn{1}{c|}{ Mollusc species } \\
\hline 1 & 243 & Pinus cf. sylvestris & Spondylus fragments (marine shell) \\
\hline 2 & 191 & Pinus cf. sylvestris & $\begin{array}{l}\text { Vallonia costata shells (2 pieces), terrestrial } \\
\text { species, Macrogastra ventricosa peak (1 piece) }\end{array}$ \\
\hline 3 & 136 & $\begin{array}{l}\text { Pinus cembra, a cold climate } \\
\text { indicator species }\end{array}$ & $\begin{array}{l}\text { Trichiahispida shell (4 pieces), terrestrial } \\
\text { species. Discus ruderatus shell(1 piece) }\end{array}$ \\
\hline 4 & 335 & $\begin{array}{l}\text { Pinus cembra, a cold climate } \\
\text { indicator species }\end{array}$ & $\begin{array}{l}\text { Trichiahispida shell (1 piece), terrestrial species. } \\
\text { Discus ruderatus shells (2 pieces), } \\
\text { Succinea oblonga shells (3 pieces) }\end{array}$ \\
\hline
\end{tabular}


Fragments of mollusc shell (e.g. Spondylus-marine shell) might have been collected by ancient communities or could also have been blown by the sirocco wind from the beach. Therefore, they will not be discussed further in the paper.

The charcoal bed ( $70-100 \mathrm{~cm}$ below the actual level) (Fig. $4 \mathrm{~b}$ and $\mathrm{c}$ ) was ${ }^{14} \mathrm{C}$ dated to the $15^{\text {th }}$ and $16^{\text {th }}$ centuries $A D$ (Table 7). The analyses revealed that charcoal originates from the Pinus sylvestris group ( $P$. sylvestris; $P$. mugo; P. nigra; $P$. cembra) most likely Pinus cf. sylvestris and Pinus cembra, the latter being the cold climate indicator species. Several pieces of Discus ruderatus, often found in coniferous forests, were found in samples 3 and 4 (Table 6), as was the case in the Milna valley, but today this species is usually found at higher altitudes. The aforementioned species are dated to 781, and $854 \mathrm{cal}$ AD (Table 7), so they lived during the Dark Age Cold Period (DACP).

Above the river bed, dated by charcoal to 1438 - 1564 cal AD (Table 7), $1 \mathrm{~m}$ of sediments have been accumulated during the last 550 years, i.e. a $\sim 2 \mathrm{~mm} / \mathrm{yr}$ accumulation rate. However, these sediments are strongly anthropogenically influenced (reworked).

Table 7 Results of ${ }^{14} \mathrm{C}$ analyses of the charcoal and molluscs samples in relation to the analysed layers (horizons) of the Milna valley

\begin{tabular}{|c|c|c|c|c|c|c|}
\hline Lab no. & $\begin{array}{c}\text { Sample } \\
\text { description }\end{array}$ & $\delta 13 \mathrm{C}$ & $\mathrm{pMC}$ & $\begin{array}{c}\text { Conventional } \\
14 \text { C Age (BP) }\end{array}$ & $\begin{array}{c}\text { Calibrated range } \\
\text { (calBC/AD) } \\
\text { (1 sigma) }\end{array}$ & $\begin{array}{c}\text { Median } \\
\text { (cal BC/AD) }\end{array}$ \\
\hline Z-4937 & $\begin{array}{c}\text { charcoal, } \\
\text { sample 1 }\end{array}$ & -24.2 & $96.45 \pm 0.31$ & $290 \pm 25$ & $1523-1650$ & 1564 \\
\hline Z-4938 & $\begin{array}{c}\text { charcoal, } \\
\text { sample 4 }\end{array}$ & -24.4 & $94.4 \pm 0.32$ & $462 \pm 27$ & $1427-1448$ & 1438 \\
\hline Z-4939 & $\begin{array}{c}\text { gastropod shell, } \\
\text { sample 1 }\end{array}$ & -6.1 & $85.79 \pm 0.32$ & $1231 \pm 29$ & $713-866$ & 781 \\
\hline Z-4940 & $\begin{array}{c}\text { mollusc shells } \\
\text { marine, } \\
\text { sample 1 }\end{array}$ & -7 & $68.46 \pm 0.26$ & $3043 \pm 30$ & cal BC $890-812$ & -857 cal BC \\
\hline Z-4942 & $\begin{array}{c}\text { gastropod shell, } \\
\text { sample 4 }\end{array}$ & -5.3 & $86.47 \pm 0.29$ & $1167 \pm 26$ & $777-894$ & 854 \\
\hline $\begin{array}{c}\text { mallusc shells } \\
\text { sample 4 }\end{array}$ & -8.8 & $71.13 \pm 0.27$ & $2736 \pm 30$ & cal BC 534 - 409 & $-489 \mathrm{cal} \mathrm{BC}$ \\
\hline
\end{tabular}

Remains of carbonised wood from the sediments are evidence either of natural or anthropogenic palaeofires. During the $14^{\text {th }}$ and $15^{\text {th }}$ centuries this area was most likely used for agriculture. Consequently, we assume that we are dealing with human activity. Anthropogenic influences on land cover changes can be further traced from the beginning of the $19^{\text {th }}$ century through present day, by means of different cartographic sources.

\subsection{Land cover changes from 1834 to present day}


The map from the 1834 cadastre shows that the majority of the Milna area was covered by forest. However, large areas of the valley were already covered by agricultural land (Fig. 7a).

The 1968 georeferenced orto-photos demonstrated a significant decrease in the arable land category compared to 1834 . Moreover, they showed large terraced areas covered with vineyards in different stages of abandonment (Fig. 7b). The abandonment was stronger on north-facing slopes. The (abandoned) vine terraces are mostly located in areas which were covered by forests in 1834, suggesting that a process of forest clearing occurred during the later stages of the $19^{\text {th }}$ century. Large parts of the area were covered with very sparse vegetation or almost completely barren.

The 2009 georeferenced ortho-photos show a continuation of the trend from the previous period. Most of the agricultural areas including vineyards are now completely abandoned, with only the bottom part of the valley still cultivated. Vineyard terraces are almost completely covered by vegetation, and can be barely seen in the landscape (Fig. 7c, Table 8).

Fig. 7.

Table 8 Forest and arable land cover in Milna valley for selected years

\begin{tabular}{|c|c|c|l|}
\hline Year & Forest cover (ha) & Arable land (ha) & \multicolumn{1}{|c|}{ Trend } \\
\hline 1834 & 128 & 51 & - \\
\hline 1968 & 49 & 25 & $\begin{array}{l}\text { Decrease in both forests and arable } \\
\text { land }\end{array}$ \\
\hline 2009 & 180 & 23 & $\begin{array}{l}\text { Increase in forests and a continual } \\
\text { decrease of arable land }\end{array}$ \\
\hline
\end{tabular}

Fig. 8.

\section{Discussion}

\subsection{Origin of the charcoal/gravel layer}

Present-day characteristics of sediments depend on many factors, starting with depositional mechanisms and environment, palaeogeography, characteristics of the sedimentary basin, and anthropogenic influences. According to the field observations, the charcoal bed overlays the bed of pebbles, which points to the important energy of water flow strengthened by vegetation clearing. The flow incised the central part of the valley and formed a river bed with pebbles. It is clear that due to deforestation the temporal river (torrent) had enough energy to incise a relatively deep bed, as the sediments were soft. When the energy of the torrent flow was suddenly reduced (stopped), pebbles remained as they were (lodged in underlying soft silty sediment, as presented in Posilović et al., (2018)). These pebbles are mostly composed of dolomite (rarely limestone) with a specific gravity of $2.8-2.9 \mathrm{~g} \mathrm{~cm}^{-3}$. During aforementioned torrent flow, charcoal particles were floating in water suspension because of their specific gravity of $1.1-1.4 \mathrm{~g} \mathrm{~cm}^{-3}$, which is probably even lighter than the specific gravity 
of the whole torrent flow. When the energy of the torrent flow ran out the charcoal bed was deposited onto underlying gravel bed, thus forming a layer that archives the torrent flow. The separation of material is the result of the significant difference in specific gravity of the two main constituents in the flow (pebbles, charcoal), and of water energy and flow pattern (Schindfessel, et al., 2015).

Modal analyses indicate that mineral composition of siliciclastic detritus of analysed samples is similar to the modal composition of soil samples from Lumbarda on the island of Korčula, indicating polygenetic origin of siliciclastic detritus (Romić et al., 2012, 2014). A part of the mineral composition is influenced by minerals from the Alpine region with significant influence of material from the Dinaride Ophiolite Zone (Pamić et al., 2002, Robertson et al., 2009). However, in Lumbarda there is higher portion of HMF (almost exclusively amphiboles, pyroxenes and epidote-zoisite group of minerals), a lower amount of opaque minerals, and the transparent heavy minerals are not so fresh (Romić et al., 2012, 2014). This is quite certainly due to the exposure of soil samples to pedogenic weathering (the samples originate from a vineyard). Moreover, the same mineral composition of HMF indicates the same origin of sediment: the Dinaride Ophiolite Zone in Bosnia, transported by the Neretva River through Dinaric karst and sedimentation in the form of alluvial sediment to the area of today's MidAdriatic islands (e.g. Babić et al., 2013; Pavelić et al., 2014) - an area that was part of the mainland in the Pleistocene (Fig. 9).

All analysed samples are rich in $\mathrm{Ca}$ and $\mathrm{Mg}$. Since the valley was formed in the Middle Cretaceous (Cenomanian), dolomite, alluvial and colluvial inputs of dolomite-derived materials obviously increased the content (e.g. sample 4). Peh et al. (2008) statistically proved that alluvium is typically enriched in Ca and Mg, however, Kassai and Sisák (2018) pointed out that the spatial distribution of $\mathrm{Ca}$ and $\mathrm{Mg}$ in alluvial clay could differ. In this study a positive correlation between shares of the clay fraction and of $\mathrm{Mg}$, $\mathrm{Fe}, \mathrm{Na}$ and $\mathrm{K}$ contributions have been observed in all samples. Therefore, it can be concluded that they are predominantly accumulated in the clay fraction (Tables 4 and 5). It could be further assumed that the highest measured concentrations of $\mathrm{Fe}, \mathrm{Na}, \mathrm{K}$ and $\mathrm{Mg}$ in the finest sample probably indicate their role as constructional elements of clay minerals and/or as cations adsorbed on their surfaces (Oreščanin et al., 2005; Galović, 2014). Their distribution seems to be related to fluvial and slope dynamics within the valley, i.e. flow patterns (Schindfessel et al., 2015).

The water-soluble element content can be traced to the recoverable element content of soils (Bohn et al. 2002). Therefore, the high water-soluble Mg, K, Na, Fe (Lehmann et al. 2003) element content from the analysed soil level suggests that an organic farming system with manuring occurred on the analysed soil surface during historic time.

The modal composition from the Milna valley corresponds to ranges found in previous research (Babić et al., 2013; Pavelić et al., 2014). The slightly increased content of epidotezoisite group of minerals found in this research could be due to the influence of the Cetina River (Fig. 9), as a partial source, especially keeping in mind the palaeowind direction from the 
NW quadrant. The palaeowind direction was reconstructed on dune positions on the MidAdriatic islands (Fig. 13 in Pavelić et al., 2014). Furthermore, Babić et al. (2013) discuss possible palaeotransport from SE. The large Drin River (Albania) debouches into the Adriatic Sea and may have contributed an important part of pyroxenes and amphiboles. Thus, according to the principle of actuality, palaeotransport was performed by wind and by the Adriatic Sea currents.

Fig. 9.

In both aforementioned publications, the authors concluded that aeolian deposits are often intercalated with alluvial deposits. Alluvial sediments could be thus resedimented by wind and deposited as aeolian sediments (Babić et al., 2012, 2013; Pavelić et al., 2014). Likewise, considering the composition (dominated by weathered quartz grains and lithic particles, mostly intensively weathered quartzite, chert, shale and schist) and share of LMF (about 90\%), it can be confirmed that most of the material was intensively weathered and probably redeposited multiple times before deposition in the Milna valley. Thus, the Pleistocene alteration of wet (sedimentation of floodplains) and dry (sedimentation of sand dunes) climate enabled accumulation of siliciclastic material on Vis and weathering and erosion of that material in the Milna drainage basin during the Holocene.

On the other hand, in HMF, most of the grains are very fresh and some of them have preserved terminal surfaces (Fig. 5a and d), indicating lack of physical erosion and weathering during transport and after sedimentation. Strait extinction of quartz grains and inclusions in fresh quartz (Fig. 5a) and feldspar grains indicate their volcanic origin. Appearance and contribution of unresisting minerals (pyroxenes and amphiboles) indicate a lack of resedimentation and a probable volcanic origin of those mineral grains. This is confirmed by the low W.I. Mineral composition of HMF, indicating neutral to basic volcanism as a possible origin of the analysed material. However, the lack of volcanic glass could be explained by its expected neutral to basic chemistry that could allow its intensive weathering (Lugović et al., 2006; Radić et al., 2007). Based on Kovačić et al. (in press), in the Milna valley volcanic glass was probably sedimented on the land too, but, because of atmospheric conditions, the grains were weathered. Thus, evidences of aeolian sedimentation and the wind direction during that time point to volcanism in Italy as one of the sources of siliciclastic detritus. It could be presumed that sediments in the Milna drainage basin have a polygenetic origin similar to terra rossa along the eastern Adriatic coast (Durn et al., 2007).

The Milna valley consists exclusively of the Middle Cretaceous (Cenomanian) dolomite and there are no outcrops of younger carbonate sediments (Fig. 2). Since the whole eastern part of Vis has dolomite bedrock, the most of analysed pebbles are dolomites, eroded from the drainage basin of the Milna valley. 
The pebble from thin-section $4 a$ is similar to Oligocene sediments from the island of Biševo (Marković-Marjanović, 1977) and Miocene of the island Palagruža (Salamandrija unit, Fig. 10 of Korbar et al. 2009). It could be also related to the Neptunian Dyke from the nearby island of Brusnik described by Babić et al. (2012). However, biogenic constituents in Pleistocene bioclastic limestone from Brusnik contain gastropods, bivalves, bryozoans, corallinaceans and echinoids, and thus differ from those analysed in sample 4a. Keeping in mind the parallel faults of the Milna-Stupišće fault zone (see chapter 3), the Neptunian Dyke could also have been formed in the Milna valley before sedimentation of Quaternary deposits. These Oligocene sediments are less resistant to weathering than surrounding Cenomanian dolomite. Consequently, they could have been more susceptible to weathering because of intensive agricultural activities during the Holocene.

The analysed pebble, represented by the thin section $2 \mathrm{a}$, is composed of silty siliciclastic detritus, indicating loess origin; whereas reddish clay minerals and Fe/Mn oxides and hydroxides, dispersed in the groundmass or concentrated in concretions, indicate pedogenetic alteration of loess. It could be assumed that there were loess deposits, and their respective palaeosols, from the Pleistocene. That material could be eroded and redeposited: loess material as loose silt and concretions (loess doll) as pebbles. Impregnation with reddish clay and $\mathrm{Fe} / \mathrm{Mn}$ oxides and hydroxides could happen after intercalation of porous loess doll in soil saturated with water. Due to the dominance of the sirocco wind and the influence of the Adriatic Sea currents (Babić et al., 2013), it is possible that patchy appearances of outcrops of these carbonates originate from the area that is today below sea level, and that they were further resedimented in the Milna valley. Vis was settled early, so anthropogenic input could be another possible source of material. This material could also have been brought from another location, e.g. as building material or as ship ballast.

\subsection{Palaeoenvironmental evolution and land cover changes}

This study revealed that between 470 and 900 AD (Cisneros et al., 2016) during the DACP period, and most probably also prior to it, the Milna valley was covered by forests. We determined that Pinus sylvestris and Pinus cembra were the major tree species. Natural vegetation, defined from charcoal together with mollusc species found in the samples, revealed the natural ecological conditions and relatively colder conditions during the DACP on Vis. These species are found today in the mid-mountain zone of Velebit Mt., and are also typical in Weichselian loess - sand layers from the island of Susak (Rudner and Sümegi, 2001; Sümegi, 2003; Rudner, 2003). During the DACP period cold climates were common in the Northern Hemisphere. There are also suggestions that some regions may have been relatively wet during the DACP, while those around the Mediterranean indicate coinciding droughts (Helama et al., 2017). However, several species found in the Milna valley, like Macrogastra ventricosa, Trichia hispida, and Succinea oblonga, could also be related to the more humid habitat and therefore point to more humid climate on Vis during that period. 
According to available sources, up until the late medieval period, the main economy of Vis was agriculture and pasturing, with the main settlements as well as the agricultural land (fertile karst poljes) located in the island's interior (Peričić, 1999). The use of fertile soils favoured by mild climate represented an obviously good base for agricultural activity (Husnjak et al., 2008). However, during that time the majority of the island was covered by forest and maquis.

The extent of forests and agricultural land on the Vis Island during the past often depended on different economic circumstances and practices. They include pasturing, sourcing of wood for fuel, and agricultural expansion, which have caused degradation of autochthonous forests throughout the Mediterranean in the past (Hughes, 2005; Scarascia-Mugnozza et al., 2000). However, unlike in other parts of Europe, the regeneration of forests in the Mediterranean was more difficult because of the seasonality of the regional climate, the more frequent occurrence of fires, and overgrazing (particularly by goats). The result was the succession of an inferior woodland, usually degraded forests and maquis (Williams, 2000). The most degraded areas on Vis today are located right around the settlements on the upper parts of slopes surrounding island's karst poljes, where the original forests have almost completely disappeared (Lozić et al., 2012).

This study revealed that the Milna valley was covered by forests until the $15^{\text {th }}$ century when it was burned (according to our records) for the first time considering the last 2000 years. The clearing of the Milna valley indicate that agricultural activity had moved to the coastal valleys in the $15^{\text {th }}$ century. This change of habitat could be related to the historical battles, e.g. in 1483 when a large part of the interior of Vis was destroyed and burned during the Italian Wars, especially the island's main settlement at the time-Velo selo (today called Podselje) (Fig. 1). This was a turning point in the islands history, because after the destruction of Velo selo, the majority of the population from the interior resettled on the island's coast and, according to Novak (1954), Peričić (1999), and Piteša (2005), turned to fishing instead of agriculture. Further destruction of inland settlements ensued after the Ottoman invasion in 1571, forcing the remainder of the populace from the interior to resettle to newly built villages on the coast (Fisković, 1977). As a consequence of these events, Venetian chronicles during the late $17^{\text {th }}$ century documented the changes in livelihood strategy of the local population-the people of Vis gradually turned to fishing and arable land was mostly left to overgrow (Novak, 1964).

However, the clearing of the Milna valley provide evidence that agricultural activity moved to the coastal valleys in the $15^{\text {th }}$ century. We demonstrate here that, even if the main livelihood on the island since the $15^{\text {th }}$ century was fishing (Peričic, 1999), the fertile valleys were still used for agriculture during that period. Consequently, despite the historical events which facilitated the process of agricultural abandonment and a shift towards fishing, the existence of agricultural land and continuous agricultural practices on the island at least since the $11^{\text {th }}$ century (mostly pasturing; Novak, 1954) and agricultural production, mostly vineyards, but also wheat cultivation, at least since the $15^{\text {th }}$ century (Peričić, 1999) can be confirmed. 
The margins of actual agricultural fields on the NE part of Vis coincide almost precisely with boundaries of aeolian sands even today (Babić et al., 2013), revealing that aeolian deposits represented a good base for soil production and agriculture (Miloš, 1986; Husnjak et al., 2008). The post-depositional processes (including human impact) have, of course, changed the surface of the studied deposits. It seems that agricultural abandonment on Vis at the time was selective, and that factors such as relief, geographical location close to the coastline, and soil fertility played a role in this process.

The $15^{\text {th }}$ and $16^{\text {th }}$ century fires in the Milna valley obviously relate to anthropogenic influences as human activity seems to be the major driver of fires since about $2000 \mathrm{BP}$ and fire occurrence increase up to the present day (Lloret et al., 2009). This trend has been well-illustrated by charcoal peaks obtained elsewhere, e.g. in the Iberian Peninsula corresponding to periods of intense landscape transformation during the Roman agricultural expansion (c. $2000 \mathrm{BP}$ ), the medieval increase in grazing area (c. 1500 - 1300 and 1000 BP) and, more recently, after the $18^{\text {th }}$ century population increase (Riera-Mora and Esteban-Amat, 1994). Consequently, forest fires (anthropologic or natural) are considered as an important component in Mediterranean ecosystems responsible for late Holocene vegetation changes.

Beneath charcoal bed, in the central part of the Milna valley, there is a fluvial facies originated by temporary streams as indicated by pebbles. They formed elongated bodies overlying aeolian deposits which could be correlated to the last (seventh) phase of the climate change of Marković-Marijanović (1977). Neighbouring carbonate (dolomite) slopes were a principal source of this material. A narrow river bed inside the valley relates to heavy rains and rainstorms, that is, to a wet period. This wet period, according to our chronology and the phase of bed formation, relates to Little Ice Age (LIA) period. Relatively wetter conditions during parts of the LIA period have already been identified along the eastern Adriatic coast through the enhanced input of fresh water in the Mirna river valley in Istria (Kaniewski et al., 2016) and in the stalagmite records around Zadar area (Rudzka et al., 2012).

These are typical sedimentary successions along the eastern Adriatic where aeolian and alluvial deposits are intercalated (Marković-Marjanović, 1976). The deposits formed successions in which aeolian sediments reflect mostly dry intervals, while alluvial deposits reflect wet intervals, indicating strong climatic controls on sedimentary environments (Kovačić et al., in press), also observed in this study in the 1.5 ka scale and assisted by anthropogenic influences.

Fires dated to the $15^{\text {th }}$ and $16^{\text {th }}$ centuries in the Milna valley coincide with the expansion of vineyards which started on the island as early as the $15^{\text {th }}$ century (Peričić, 1999), but, as discussed, this could also be related to historical battles which occurred on the island in 1483 and 1571. The process of deforestation appeared to continue in the following centuries, and was especially notable during the $17^{\text {th }}$ century, when a decree was brought which reduced 
cattle grazing in forested areas of the island to prevent further destruction of forests (Peričić, 1999).

Studying further the land cover changes it was discovered that, in 1834, large areas of the Milna valley were still covered by forests, even though a substantial area was used as agricultural land (Fig. 7, Table 8). According to available data, in the mid-19 ${ }^{\text {th }}$ century around $50 \%$ of the island $(8,500 \mathrm{ha})$ was covered by forests, but it remains unclear which types of vegetation were actually considered forests (Peričić, 1999). Despite the questionable level of certainty of early $19^{\text {th }}$ century data, it is assumed that most of the arable land at the time was vineyards, which covered around $22 \%$ of the island (Peričić, 1999).

Between the two cartographically documented years 1834 - 1968 (Fig. 7) the agricultural expansion in the Milna valley was the strongest and is evidenced in numerous now fossilised terraces in the valley (Fig. 8). The main impetus for the expansion of agricultural land (almost exclusively of vineyards) on Vis came after powdery mildew was discovered in Italy in 1858 and Grape phylloxera in France in 1874 which resulted in a near-total collapse of the wine industry in both countries. It was a great incentive for local grape growers and by the end of the $19^{\text {th }}$ century, mostly as a consequence of forest clearing, the total surface of arable land on the island had doubled (Peričić, 1999) - taking less than 20 years-with over $95 \%$ of all arable land on Vis covered by vineyards. This important agricultural expansion coincided with the demographic peak on the island during the late $19^{\text {th }}$ and early $20^{\text {th }}$ centuries (population of around 10,000 people according to the 1910 Census) (Nejašmić and Mišetić, 2006).

The gradual decline of wine industry on the island started after the "Vine clause" was signed between Italy and Austria-Hungary in 1891 and the arrival of Grape phylloxera on the island in 1894 (Perić, 1987). The evidence of this decline can be seen in Fig. 8. The abandoned terraces were probably built during the aforementioned grape-growing boom and are mostly located in areas which were covered by forests in 1834, suggesting that processes of forest clearing and agricultural expansion were prevalent during that period. The 1968 images also show that the agricultural abandonment as a consequence of grape vine disease was stronger on north-facing slopes, compared to the south-facing ones, demonstrating selectivity in agricultural abandonment process where less favourable areas were abandoned first. Generally, the natural vegetation is strongly reduced in the considered period, from 128 ha in 1834 to 49 ha in 1967 (Table 8, Fig. 7).

This agricultural abandonment on Vis (observed in the Milna valley) was further facilitated by socio-political development in Yugoslavia after the Second World War when Vis became one of the most important naval bases in the country, which had a profound impact on its social and economic development. The population mostly emigrated to larger coastal settlements, and the number of people living on the island halved from 1953 to 1991 (Nejašmić and Mišetić, 2006) and dropped to 3,617 people according to the 2011 Census. These processes coincided with the continual of agricultural abandonment as well as natural afforestation which 
progressed (mainly pine) in the Milna valley during the second half of the $20^{\text {th }}$ century (Table 8, Fig. 7).

The analysis of the satellite imagery between 1990 and 2010 demonstrate a 9\% increase in the natural vegetation category on the entire island (Deriš, 2016), emphasizing the process of agricultural abandonment seen on the 1968 - 2009 ortho-photos (Fig. 8). This is further confirmed by the land cover change data from the CORINE database. According to CORINE, from 1980 to 1990, the main category of land cover change on the island were different stages of secondary succession, which encompassed 64\% (305 ha) of all land cover changes on the island. Between 1990 and 2000 land cover changes were less intensive, and the strongest was related to different stages of forest degradation (75\%, $181 \mathrm{ha}$ ), probably as a result of wildfires (Pavlek et al., 2017). During the last phase, between 2000 and 2012, the only important land cover change on the island was a small increase in vineyards which covered 139.5 ha, as a result of stronger tourist development in recent years and a recent general expansion of the wine industry in Croatia. The 2013 georeferenced ortho-photos further corroborate a continuation of this rapid agricultural abandonment which started at the beginning of the $20^{\text {th }}$ century.

The collapse of the agricultural activities has not affected all surrounding islands in the same way, e.g. in Sveta Nedjelja on the island of Hvar more or less the same surface area is used for agricultural purposes today as in 1834 (Faivre and Mićunović, 2017).

Due to recent relative sea level rise (Faivre et al., 2013) and vineyard expansion, there was a need for protection of arable land and thus for the construction of a bigger wall at the mouth of the Milna valley. The response of low coasts, formed in unconsolidated sediments, to sealevel rise has been the subject of considerable scientific research, particularly on sandy shores. It is difficult to take account of the "sea-level rise" parameter in quantifying shoreline evolution (Dubois, 2002). Brunel and Sabatier (2009) adopt the principle of dynamic-active submersion for sandy beaches, assuming that the slope of the beach profile remains identical in time and migrates horizontally towards the land when sea level rises in the case of no major sediment input and if there is space available in the background. This landward migration of the scarp, due to sea-level rise, obviously occurred in the Milna valley up until the natural process was stopped by the building of stone walls. Thus, between 1976 and $2009-2011$ the reduction of the beach size is estimated to $\sim 10 \pm 2 \mathrm{~m}$. This is the consequence of the recent acceleration of relative sea-level rise in transition from LIA to Current Warm Period as evidenced on the Vis, Biševo, and Ravnik islands based on fixed biological indicators, that is, on algal rims (Faivre et al., 2013).

Likewise, many valley mouths along the eastern Adriatic coast have been modified (dammed) with different kind of walls, mostly dry-walls. Those structures were used primarily to prevent soil erosion as the valleys generally represented areas with potentially fertile soil, rare in karst areas. Consequently, such structures also directly influence the sediment supply to the beach 
(Faivre et al., 2011). These structures may thus disable natural backward migration of the beach due to relative sea level rise, like in the case of the Milna valley.

Most of the gullies and valleys on the island of Krk, for example, were inactive (dry) during the second part of the $20^{\text {th }}$ century, even in periods of intensive rainfalls (Benac, 1992). But recently those valleys have become active again as a consequence of increasing frequency of extreme events due to climate change (Faivre et al., 2011; Kaniewski et al., 2016), strongly influencing beach morphology.

\section{Conclusion}

Modal composition and habitus of most analysed grains from matrix of the layer indicate the Dinaric Ophiolite Zone (DOZ) as a source of material and transport of material by the Neretva River and possible influence of the Cetina and Drin Rivers. On the other hand, very fresh grains of HMF with preserved terminal surfaces indicate lack of physical erosion and weathering during transport and after sedimentation. Mineral composition of these grains implies neutral to basic volcanism as possible origin of part of analysed material. Based on wind direction of that time and evidences of aeolian sedimentation, one of the sources of siliciclastic detritus could be volcanism in Italy. This led to the conclusion on polygenetic origin of source material from the Milna drainage basin.

The grain-size composition, roundness, and sorting of analysed samples is typical for torrent flows. Most of the pebbles are sub-rounded clasts of the Middle Cretaceous (Cenomanian) dolomite that forms the Milna valley, indicating the predominance of local fluvial transport. However, pebbles without related outcrops in the Milna valley could represent the remains of eroded lithological units. To date, an outcrop of Neogene fossiliferous limestone has not been found in the Milna drainage basin. One of the possible explanations for this is that the analysed pebble (4a) is a remnant of an eroded lithological unite, as such limestone is not resistant to physical weathering. In that case, a Neogene fossiliferous limestone unit could still exist (as a source material) somewhere beneath Quaternary sediments. The other explanation of origin of fossiliferous limestone pebble implies anthropogenic influence since the island of Vis has been inhabited since prehistoric times. This material could have been brought from another location as building material or as ship ballast and resedimented by torrent flow, together with local clasts from the Milna valley.

The natural vegetation of Pinus sylvestris and Pinus cembra with closed forest habitat preferring and cold resistant species found in the samples reflect natural ecological conditions of the studied area during the DACP. Thus, we revealed relatively colder conditions on Vis during that period. According to the dated charcoal, we found that the agricultural (anthropogenic) activities started to impact the valley in the $15^{\text {th }}$ and $16^{\text {th }}$ centuries when natural wood vegetation was burned, providing firm evidence that agricultural activities moved to coastal areas during that period. Anthropogenic activities impact on the landscape and influenced the formation of the torrent flows in the middle of the valley. Fluvial erosion 
was induced by deforestation and also by relatively colder and wetter conditions during the LIA in the studied area. We further demonstrated the increasing impact of agriculture on landscape which culminated in the second part of the $19^{\text {th }}$ century, when agricultural activity occupied the largest part of the Milna valley. The expansion of agricultural activity resulted in further vegetation clearing and expansion of viticulture on slopes where vineyard terraces were built. After the decline of grape vine cultivation starting at the end of the $19^{\text {th }}$ century, afforestation began and has continued to present day. The collapse of agricultural activities has progressively led to the regeneration of vegetation. In the most recent period, the valley mouth is threatened by relative sea level rise resulting in the reduction of the beach size as the natural backward erosion is stopped due to anthropogenic activities (i.e. with the construction of a wall).

Here we provided an example of late Holocene evolution of the fluviokarstic valley in the typical Mediterranean conditions, deepening our understanding of Holocene deposition, late Holocene climate, landscape, and ecosystem change, together with changes in nature and the intensity of human activity on the island of Vis. We also provided new insights into land cover changes that are an important issue for the environmental evolution on the Adriatic islands. Furthermore, this study also highlights the importance of an interdisciplinary approach in palaeoenvironmental reconstructions.

\section{Acknowledgements:}

This research was supported the Ministry of Science, Education and Sport of the Republic of Croatia (project no, 119-1191306-1305), the University of Zagreb Grants for research on the Influence of palaeo and recent climate changes on processes in marine and continental environments in 2016 (no. 20281602), and by Croatian Science Foundation under the project 4425. We are especially grateful to Christopher Kaufmann for language editing. 


\section{References:}

Ambert, P., Nicod, J., 1986. Probleme geomorphologique de la Slovenie et de la Croatie septentrionals. Revue Geographic de l'EstXXVI (1-2) 3-25.

Babić, Lj., Crnjaković, M., Asmerom, Y., 2012. Uplifted Pleistocene marine sediments of the Central Adriatic Island of Brusnik. Geol. Croat. 65 (2), 223-232.

Babić, Lj., Zupanić, J., Vidović, J., Razum, I., Lužar-Oberiter B, Crnjaković, M., 2013. Preservation of hanging aeolian deposits in insular karst depressions: sediment sources and implications for the Pleistocene palaeogeography of the SE Adriatic archipelago. Aeolian Res. 11, 171-189.

Bahtijarević, A., Faivre, S., 2016. Quantitative comparative geomorpholgical analysis of Floridan fluvial and karstic relief. Environ. Earth Sci. 75 (428) doi: 10.1007/s12665-016-53978.

Ballut, C., Faivre, S., 2012. New data on the dolines of Velebit mountain: An evaluation of their sedimentary archive potential in the reconstruction of landscape evolution. Acta Carsologica 41 (1), 59-74.

Belak, M., Koch, G., Grgasović, T., Vlahović, I., Velić, I., Sokač, B. \& BenčeK, Đ., 2005. Novi prinosi stratigrafiji evaporitno-karbonatno-klasatično-vulkanogenog kompleksa Komiškog zaljeva (otok Vis, Hrvatska) [New Contribution to the Stratigraphy of Evaporitic-CarbonateClastic-Volcanogenic Complex of Komiža Bay (Island of Vis, Croatia) - in Croatian]. In: Velić, I., Vlahović, I., Biondić, R. (Eds.), 3rd Croatian Geological Congress, Opatija 29.09.-01.10. 2005., Abstract Book, Croatian Geological Survey, Zagreb, 13-14.

Benac, Č., 1992. Recentni geomorfološki procesi i oblici u području Riječkog zaljeva [The Recent Geomorphological Processes in the Area of the Rijeka Bay - in Croatian, with an English Abstract]. Geografski glasnik 54, 1-18.

Bočić, N., Faivre., S., Kovačić, M., Horvatinčić, N., 2012. Cave development under the influence of Pleistocene glaciation in the Dinarides - an example from Štirovača Ice Cave (Velebit Mt., Croatia). Z. Geomorph. N.F. 56 (4), 409-433.

Bohn, H. L., Myer, R. A., \& O'Connor, G. A. (2002). Soil chemistry. John Wiley \& Sons, New York.

Bögli, A., 1980. Karst Hydrology and Physical Speleology.Springer Verlag, pp. 284.

Bognar, A., Faivre, S., Pavelić, J., 1991. Tragovi oledbe na Sjevernom Velebitu. Geografski glasnik 53, 27-39.

Bognar, A., Faivre, S., 2006. Geomorphological traces of the younger Pleistocene glaciation in the central part of the Velebit Mt. Hrvastki geografski glasnik, 68 (2), 19-30.

Brewer, R., 1976. Fabric and Mineral analysis of Soils. Krieger, Huntington, New York, pp. 482.

Briggs, D., Smithson, P., Addison, K., Atkinson, K., 1997. Fundamentals of the physical environment, Routledge, pp. 262.

Brunel, C., Sabatier, F., 2009. Potential influence of sea-level rise in controlling shoreline position on the French Mediterranean Coast.Geomorphology 107, 47-57.

Buurman, P., Pape, T., Muggler, C.C., 1997. Laser grain-size determination in soil genetic studies 1. Practical problems. Soil Science 162, 211-218. 
Cisneros, M., Cacho, I., Frigola, J., Canals, M., Masqué, P., Martrat, B., Casado, M., Grimalt, J.O., Pena, L.D., Margaritelli, G., Lirer F. 2016. Sea surface temperature variability in the central-western Mediterranean Sea during the last 2700 years: a multi-proxy and multi-record approach, Clim. Past, 12:849-869 doi:10.5194/cp-12-849-2016.

Crnolatac, I., 1953. Geologija otoka Visa. Geološki vjesnik V-VII, 45-61.

Dániel, P., 2004. Methods of the five-step extraction-digestion method. Results of the fivestep extraction-digestion method. In: Sümegi, P., Gulyás, S. (Eds.) The geohistory of Bátorliget Marshland. Archaeolingua Press, Budapest, 53-56 and 98-108.

Deriš, F., 2016. Daljinska istraživanja promjene vegetacijskog pokrova na primjeru odabranih jadranskih otoka (Remote sensing of vegetation cover change on selected Adriatic islands), Master Thesis, University of Zagreb, Faculty of Science Zagreb, pp. 55.

Dubois, R.N., 2002. How does a barrier shoreface respond to a sea-level rise? Journal of Coastal Research 18, Editorial, iii-v.

Duplančić Leder, T., Ujević, T., Čala, M., 2004. Duljine obalne crte i površine otoka na hrvatskom dijelu Jadranskog mora određene s topografskih karata mjerila 1:25 000. Geoadria 9 (1), 5-32.

Durn, G., Aljinović, D., Crnjaković, M., Lugović, B., 2007. Heavy and light mineral fractions indicate polygenesis of extensive terra rossa soils in Istria, Croatia. In: Mange, M. A., Wright, D.T. (Eds.) Heavy Minerals in Use. Dev Sedim. 58, 701-737.

Fairbanks, R.G., 1989. A 17,000-year glacio-eustatic sea level record: influence of glacial melting rates on the Younger Dryas event and deep-ocean circulation. Nature 342, 637-642, doi:10.1038/342637a0.

Faivre, S., 1991. Geomorphological properties of the Northern Velebit, graduate thesis. University of Zagreb, Faculty of Science, pp. 75.

Faivre, S., Bakran-Petricioli, T., Horvatinčić, N., 2010. Relative Sea-Level Change during the Late Holocene on the Island of Vis (Croatia) - Issa harbour archaeological site. Geodinamica Acta 23 (5-6), 209-223.

Faivre, S., Bakran-Petricioli, T., Horvatinčić, N., Sironić, A., 2013. Distinct phases of relative sea level changes in the central Adriatic during the last 1500 years - influence of climatic variations? Palaeogeography, Palaeoclimatology, Palaeoecology 369, 163-174.

Faivre, S., Pahernik, M., Maradin, M., 2011. The Gully of Potovošća on the Island of Krk - The effects of a short-term event. Geol. Croat. 64 (1), 64-76.

Faivre, S., Mićunović, M., 2017. Reconstructing recent beach morphological changes by repeat photopgraphy - example of Zogon beach on the island of Hvar (Central Adriatic), Geoadria 22 (2), 165-192.

FAO/ISRIC/ISSS, 2006. World reference base for soil resources. World Soil Resources Reports 103.FAO, Rome.

Fisković, C., 2017. Turski napadaj na Hvar 1571, Čakavska rič, 6 (2), 111-118.

Ford, D.C., Williams, P.W., 2007. Karst Hydrogeology and Geomorphology. John Wiley \& Sons, pp. 562. 
Fürst-Bjeliš, B., Lozić, S., 2006. Environmental impact and change on the Velebit Mountain, Croatia: and outline of the periodization. In: Armiero, M. (Ed.) Environmetal Stories from the Mediterranean World (19th-20th centuries 12th-13th September 2003., Napoli, Italy. Consiglio Nazionale delle Richerce, Istituto di Studi sulle Società del Mediterraneo, 127-139.

Fürst-Bjeliš, B., Lozić, S., Perica, D., 2001. Man and the environment in the central Velebit area - Baške Oštarije and surroundings. Acta Geographica Croatica 35, 111-132.

Galović, L., 2014. Geochemical archive in the three loess/paleosol sections in the Eastern Croatia: Zmajevac I. Zmajevac and Erdut. Aeolian Res. 15, 113-132.

Gams, I., 1991. Systems of adapting the littoral Dinaric karst to agrarian land use. Geografski Zbornik 31, 5-106.

Grandić, S., Boromisa-Balaš, E., Šušterčić, M., 1997. Exploration concept and characteristics of the Dinarides stratigraphic and structural model in the Croatian offshore area. Part 1, Nafta 4, 117-128.

Grandić, S., Kratković, I., Rusan, I., 2010. Hydrocarbon potential assessment of the slope deposits along the SW Dinarides carbonate platform edge. Nafta 61 (7-8), 325-338.

Greguss, P., 1945. A középeurópai lomblevelű fák és cserjék meghatározása szövettani alapon (Xylotomy of Central European trees and shrubs). Országos Magyar Természettudományi Múzeum, Budapest.

Greguss, P., 1972. Xylotomy of the living conifers. Akadémia Kiadó, Budapest.

Hughes, J.D., 2005. The Mediterranean: An Environmental History (Nature and Human Societies Series), ACB CLIO, Santa Barbara, USA, pp. 333.

Helama, S., Jones, P.D., Briffa, K.R., 2017. Dark Ages Cold Period: A literature review and directions for future research, Holocene 27(10), 1600-1606.

Husnjak, S., Perica, D., Kušan, V., Crević, T., Kaučić, D., 2008. Usable value and potential for irrigation of karst field soils on the islands of Vis and Biševo. Hrvatske vode 16 (24), 179-189.

Kaniewski, D., Marriner, N., Morhange, Ch., Faivre, S., Otto, T., Van Campo, E., 2016. Solar pacing of storm surges, coastal flooding and agricultural losses in the Central Mediterranean, Scientific Reports, 25197 (2016), doi:10.1038/srep25197.

Kaniewski, D., Marriner, N., Morhange, C., Rius, D., Carre, M.-B., Faivre, S., Van Campo, E., 2018. Croatia's mid-Late Holocene (5200-3200 BP) coastal vegetation shaped by human societies, Quaternary Science Reviews 200, 334-350.

Kassai, P., Sisák, I., 2018. The role of geology in the spatial prediction of soil properties in the watershed of Lake Balaton, Hungary. Geologia Croatica 71(1), 29-39.

Konert, M., Vandenberghe, J., 1997. Comparison of layer grain size analysis with pipette and sieve analysis: a solution for the underestimation of the clay fraction. Sedimentology 44, 523535.

Korbar, T., 2009. Orogenic evolution of the External Dinarides in the NE Adriatic region: a model constrained by tectonostratigraphy of Upper Cretaceous to Paleogene carbonates. Earth-Sci. Rev. 96/4, 296-312. 
Korbar, T., Montanari, A., Koch, G., Mariani, S., DePaolo, D., Turchyn, A., Miknić, M., Tari, V., 2009. Geologic reconnaissance of the island of Velika Palagruža (central Adriatic, Croatia). Geol. Croat. 62 (2), 75-94.

Korbar, T., Belak, M., Fuček, L., Husinec, A., Oštrić, N., Palenik, D., Vlahović, I., 2012. Osnovna geološka karta Republike Hrvatske mjerila 1:50 000 - list Vis 3 i Biševo 1 (Basic Geological Map of the Republic of Croatia scale 1:50.000 - sheet Vis 3 and Biševo 1).- Hrvatski geološki institut (Croatian Geological Survey), Zavod za geologiju (Department of Geology), Zagreb, 1 list (1 sheet).

Kovačić, M., Pavelić, D., Vlahović, I., Marković, F., Wacha, L., Kampić, Š., Rončević, S., Drempetić, D. Pleistocene alluvial and aeolian deposits with tephra on the island of Lopud (eastern mid- Adriatic, Croatia): Provenance, wind regime, and climate controls. Quat. Int., in press. https://doi.org/10.1016/j.quaint.2017.11.054

Krajcar Bronić, I., Horvatinčić, N., Sironić, A., Obelić, B., Barešić, J., Felja, I., 2010. A new graphite preparation line for AMS $14 C$ dating in the Zagreb Radiocarbon Laboratory. Nuclear Instruments and Methods in Physics Research Section B: Beam Interactions with Materials and Atoms 268 (7/8), 943-946.

Krklec, K., Lozić, S., Šiljeg, A., 2012. Geomorphological Features of the Vis Island. Naše more 59 (5-6), 290-300.

Lambeck, K., Purcell, A., 2005. Sea-level change in the Mediterranean Sea since the LGM: model predictions for tectonically stable areas. Quat. Sci. Rev. 24, 1969-1988.

Lehmann, J., da Silva, J. P., Steiner, C., Nehls, T., Zech, W., \& Glaser, B. (2003). Nutrient availability and leaching in an archaeological Anthrosol and a Ferralsol of the Central Amazon basin: fertilizer, manure and charcoal amendments. Plant and soil 249 (2), 343-357.

Lloret, F., Piñol, J., Castellenou, M., 2009. Wildfires. In: Woodward, J. (Ed.), The Physical Geography of the Mediterranean. Oxford University Press 541- 558.

Lozić, S., Šiljeg, A., Krklec, K., Šiljeg, S. 2012. Vertical landscape structure of the southern part of Vis Island, Croatia, Dela 37, 65-90.

Lugović, B., Crnjaković, M., Biševac, V., 2006. Mineralogical signatures of weathered Late Holocene ash layer from the island of Mljet in Croatia. In: Vlahović I., Tibljaš, D., Durn, G., Biševac, V. (Eds.), $3^{\text {rd }}$ mid-European clay conference-MECC 06. Abstract Book, Prirodoslovnomatematički fakultet and Rudarsko-geološko-naftni fakultet, pp 78.

Malez, M., 1972. Rasprostranjenost hladnoljubivih životinja u gornjem pleistocenu jugoistočne Evrope. Rad Jugosl. akad. znan. i umjet. 346, 133-180.

Mange, M.A., Maurer, H.F.W., 1992. Heavy Minerals in Colour. Chapman and Hall, London. pp. 147.

Marković-Marjanović, J., 1976. Kvartarni sedimenti ostrva Hvara - srednji Jadran, Glasnik prirodnjačkog muzeja, knjiga 31, serija A, 199-214.

Marković-Marjanović J., 1977. Kvartar na ostrvu Visu. Glasnik prirodoslavnog muzeja u Beogradu, Serija A, Knjiga 32, 145-161. 
Mikulčić Pavlaković, S., Crnjaković, M., Tibljaš, D., Šoufek, M., Wacha, L., Frechen, M., Lacković, D., 2011. Mineralogical and geochemical characteristics of Quaternary sediments from the Island of Susak (Northern Adriatic, Croatia). Quat. Int. 234 (1-2) 32-49.

Milojević, B. Ž., 1927. Ostrvo Vis. Glasnik zemaljskog muzeja Bosne i Hercegovine, sv., 1/XXXIX, Sarajevo, 111-124.

Miloš, B., 1986. Soils of the Vis section, 1: 50000; Institute for Adriatic Crops and karst Reclamation. University of Split, Croatia.

Munsell soil color book 2013. Munsell Soil Color Charts with genuine Munsell color chips.Macbeth Division of Kollmorgem Instruments Corporation, New Windsor.

Nejašmić, I., Mišetić, R., 2006. Depopulation of Vis Island, Croatia. Geoadria, 11 (2) 283-309.

Nicod, J., 2003: Les karsts Dinariques paysages et problèmes.- Karstologia Mémoires, 10, pp.183, Ljubljana.

Novak, G., 1954. Otok Vis u srednjem vijeku. Starohrvatska prosvjeta, 3 (3), 105 - 130.

Novak, G., 1961. Vis. From $6^{\text {th }}$ century BC to 1941. Zagreb, JAZU.

Novak, G., 1964. Mletačka uputstva i izvještaji. Zagreb, JAZU. pp. 345.

Oreščanin, V., Lulić , S., Medunić , G., Mikelić , L., 2005. Granulometric and chemical composition of the Danube River sediments, Batina Village, Croatia. Geol. Croat. 58(2), 185194.

Palenik, D., 2005. Strukturni slop otoka Visa. Unpublished Master Thesis, University of Zagreb pp. 122.

Pamić, J., Tomljenović, B., Balen, D., 2002. Geodynamic and petrogenetic evolution of Alpine ophiolites from the central and NW Dinarides: an overview. Lithos 65, 113-142.

Pavelić, D., Kovačić, M., Vlahović, I., Mandic, O., Marković, F., Wacha, L., 2014. Topography controlling the wind regime on the karstic coast: late Pleistocene coastal calcareous sands of eastern mid-Adriatic, Croatia. Facies 60, 843-863.

Pavlek, K., Bišćević, F., Furčić, P., Grđan, A., Gugić, V., Malešić, N., Moharić, P., Vragović, V., Fuerst- Bjeliš, B., Cvitanović, M., 2017. Spatial patterns and drivers of fire occurrence in a Mediterranean environment: a case study of southern Croatia. Geografisk Tidsskrift-Danish Journal of Geography 117 (1), 22-35.

Peh, Z., Šajn, R., Halamić , J., Galović , L., 2008. Multiple discriminant analysis of the Drava River alluvial plain sediments. Environ. Geol. 55(7), 1519-1535.

Perić, I., 1987. Ustrojstvo i poslovanje dalmatinskog zemljišno-veresijskog zavoda (1898-1924). Radovi Zavoda za hrvatsku povijest Filozofskoga fakulteta Sveučilišta u Zagrebu 20 (1), 45 - 74

Peričić, S., 1999. The development of the economy of the island Vis in the past. Papers of Croatian Academy of Sciences and Arts in Zadar 41, 61-144.

Phillips, J., 2017. Landform transition in fluviokarst landscape. Zeitschrift für Geomorphologie, $61(2), 109-122$. 
Piteša, A., 2005. Israživanja srednjovjekovnih lokaliteta kod crkve sv.Nikole u Dolu i sv. Marije u Poselju (Velom Selu) na otoku Visu. Vjesnik za arheologiju i povijest dalmatinsku 98 (1), 213 $-241$.

Posilović, H., Galović, L., Stejić, P., Pandurov, M., Gajić, R., 2018. Quaternary depositional environments in the Vrgoračko Polje/Lake (SE Croatia). Geol. Croat. 71(3), doi: 10.4154/gc.2018.16

Prelogović, E., Pribičević, B., Ivković, Ž., Dragičević, I., Buljan, R., Tomljenović, B., 2004. Recent structural fabric of the Dinarides and tectonically active zones important for petroleumgeological exploration. Nafta 4, 155-161.

Pribičević, B., Medak, D., Prelogović, E., 2001. Usage of the geoid surface with geologicalgeophysical data for interpretation of recent crustal movements determined by GPS, EGS G9 Symposium "Geodetic and geodynamic Programmes of the CEI (Central European Initiative)", Warsaw University of Technology, Reports on Geodesy 2, 213-217.

Radić, D., Lugović, B., Marjanac, Lj., 2007. Neapolitan Yellow Tuff (NYT) from the Pleistocene sediments in Vela Spila on the island of Korčula: a valuable chronostratigraphic marker of the transition from the Palaeolithic to the Mesolithic, Opusc.archaeol. 31, 7-26.

Rajčić, S.T., Faivre, S., Buzjak, N., 2010. Preoblikovanje žala na području Medića i Mimica od kraja šezdesetih godina 20. stoljeća do danas. Hrvatski geografski glasnik 72 (2), 27-48.

Riera-Mora, S., Esteban-Amat, A., 1994.Vegetation history and human activity during the last 6000 years on the central Catalan coast (northeastern Iberian Peninsula). Vegetation history Archaeobotany 3, 7-23.

Robertson, A., Karamata, S., Šarić, K., 2009. Overview of ophiolites and related units in the Late Palaeozoic-Early Cenozoic magmatic and tectonic development of Tethys in the northern part of the Balkan region. Lithos 108 (1-4), 1-36.

Romić, M., Zovko, M., Romić, D., Bakić, H., 2012. Improvement of Vineyard Management of Vitis vinifera L. cv. Grk in the Lumbarda Vineyard Region (Croatia). Communications in Soil Science and Plant Analysis 43 (1-2), 209-218.

Romić, M., Bragato, G., Zovko, M., Romić, D., Mosetti, D., Galović, L., Bakić, H., 2014. The characteristics of cultivated soils developed from coastal paleosand (Korcula Island, Croatia). Catena 113, 281-291.

Rudner, E., Sümegi, P., 2001. Recurring Taiga forest-steppe habitats in the Carpathian Basin in the Upper Weichselian. Quaternary International 76-77, 177-189.

Rudner, E., 2003. Anthracological examinations. In: Bognar, A., Schweitzer, F., Szöör Gy. (Eds.), Susak: Environmental reconstruction of a loess island in the Adriatic. GRI HAS, Budapest, pp. 118-126.

Rudzka, D., McDermott, F., Surić, M., 2012. A late Holocene climate record in stalagmites from Modric Cave (Croatia). J. Quaternary Sci. 27 (6) 585-596.

Scarascia-Mugnozza, G., Oswald, H., Piussi, P., Radoglou, K., 2000. Forests of the Mediterranean region: gaps in knowledge and research needs. Forest Ecology and Management 132 (1), 97-101.

Schweingruber, F. H., 1990. Mikroskopische Holzanatomie (Microscopic wood anatomy). Eidgenössiche Forschungsantalt für Wald, Schnee und Landchaft, Birmensdorf. 
Šegota, T., 1966. Quaternary temperature. Changes in central Europe. Erdkunde 20 (2), 110118.

Sikora, M., Mihanović, H., Vilibić, I., 2014. Paleo-coastline of the Central Eastern Adriatic Sea, and Paleo-Channels of the Cetina and Neretva rivers during the last glacial maximum. Acta Adriat. 55 (1), 3-18.

Sümegi, P., 2003. Quartermalacological examinations. In: Bognar, A., Schweitzer, F., Szöör Gy. (Eds.) Susak: Environmental reconstruction of a loess island in the Adriatic. GRI HAS, Budapest pp. 110-117.

Sümegi, P., Magyari, E., Dániel, P., Molnár, M., Törőcsik, T., 2013. 28,000-year record of environmental change in SE Hungary: terresengtrial response to Dansgaard-Oeshger cycles and Heinrich-events. Quaternary International 278, 34-50.

Surić, M., Richards, D.A., Hoffmann, D.L., Tibljaš, D., Juračić, M., 2009. Sea-level change during MIS $5 \mathrm{a}$ based on submerged speleothems from the eastern Adriatic Sea (Croatia). Mar. Geol. $262(1-4), 62-67$.

Surić, M., Juračić, M., 2010. Late Pleistocene-Holocene environmental changes - records from submerged speleothems along the Eastern Adriatic coast (Croatia). Geol. Croat. 63 (2), 155169.

Switzer, A.D., 2013. Measuring and analyzing particle size in a geomorphic context. In: Shroder, J. (Editor in Chief), Switzer, A.D., Kennedy, D.M. (Eds.), Treatise on Geomorphology. Academic Press, San Diego, CA, vol. 14, Methods in Geomorphology, pp. 224-242.

Šušnjar, M., 1967. Stratigrafska i strukturna problematika otoka Visa. Geološki vjesnik 20, 175189.

Tzedakis, P.C., 2009. Cenozoic climate and vegetation change. In: Woodward, J.C. (Ed.), The Physical Geography of the Mediterranean. Oxford University Press, Oxford, 89-137.

Velić, J., Kljajo, D. Velić, I., 2011. Sedimentary bodies, forms and occurences in the Tudorevo and Mirovo glacial deposits of northern Velebit (Croatia). Geol. Croat. 64 (1), 1-16.

Vlahović, I., Tišljar J., Veluć, I., Matičec, D., 2002. The Karst Dinarides are composed of relics of a single Mesozoic platform: facts and consequences. Geol. Croat. 55 (2), 171-183.

Vlahović, I., Tišljar, J., Velić, I., Matičec, D., 2005. Evolution of the Adriatic Carbonate platform palaeogeography, main events and depositional dynamics, Palaeogeogr. Palaeoclim. Palaeoecol. 220, 333-360.

White, W.B., 1988. Geomorphology and hydrogeography of karst terrains, Oxford University Press. pp. 464.

Williams, M., 2000. Dark ages and dark areas: global deforestation in the deep past. Journal of Historical Geography 26 (1), 28-46.

Zaninović, K., Gajić-Čapka, M., PerčecTadić, M. Vučetič, M., Milković, J., Bajić, A., Cindrić, K., Cvitan, L., Katušin, Z., Kaučić, D., Likso, T., Lončar, E., Lončar, Ž., Mihajlović, D., Pandžić, K., Patarčić, M., Srnec, L., Vučetić, V., 2008. Climate atlas of Croatia 1961-1990., 1971-2000. Meteorological and Hydrological Service of Croatia, Zagreb, pp. 200.

Zaninović, M., 1997. Greek land division on the Island of Vis (Issa). Opcsc. archacol. 21, 77-84. 
Žebre, M., Stepišnik, U., 2016. Glaciokarst geomorphology of the Northern Dinaric Alps: Snežnik (Slovenia) and Gorski Kotar (Croatia). Journal of Maps 12, 5.

\section{List of figures:}

Fig. 1. The study area.

Fig. 2. Geological Map of the island of Vis (Korbar et al., 2012); faults in read.

Fig. 3a and b. Altitude (a) and slope inclination maps (b) of the Milna valley made by digitising topographic map of Vis (1: 25000$)$ and creating triangulated irregular network in ArcMap 10.1.

Fig. 4. a) Sampling locations in the Milna valley and approximated palaeo flow (blue dashed line). Source of image: GoogleEarth; b) profile details c) profile details.

Fig. 5. Microscopic observations of LMF and HMF. a- idiomorphic quartz crystal (crossed nicols); b- subrounded grains of LMF (reflected light); c- zonal idiomorphic sanidine cristal (1parallel and 2-crossed nicols); d- idiomorphic clinopyroxene (hedenbergite?) (parallel nicols); e- orthopyroxene (parallel nicols).

Fig. 6. Petrographic observations (plain polarised light) of pebbles from the profile. a- Crack in fine-grained crystalline dolomite filled with course-grained idiomorphic and alotriomorphic crystals of dolomite. Sample 3; b- Fe/Mn oxides and hydroxides and/or clay minerals dispersed in a groundmass or concentrated in concretions. Sample 2; c- Bioaccumulated clastic grainstone with carbonate fossils and their fragments. Sample 4.

Fig. 7. Land cover changes from 1834 to 2009.

Fig. 8. The process of agricultural abandonment observed on the 1968 - 2009 ortho-photos.

Fig. 9. The map of the Neretva and Cetina palaeo-riverbeds during Last Glacial Maximum (LGM) after Sikora et al. (2014). 


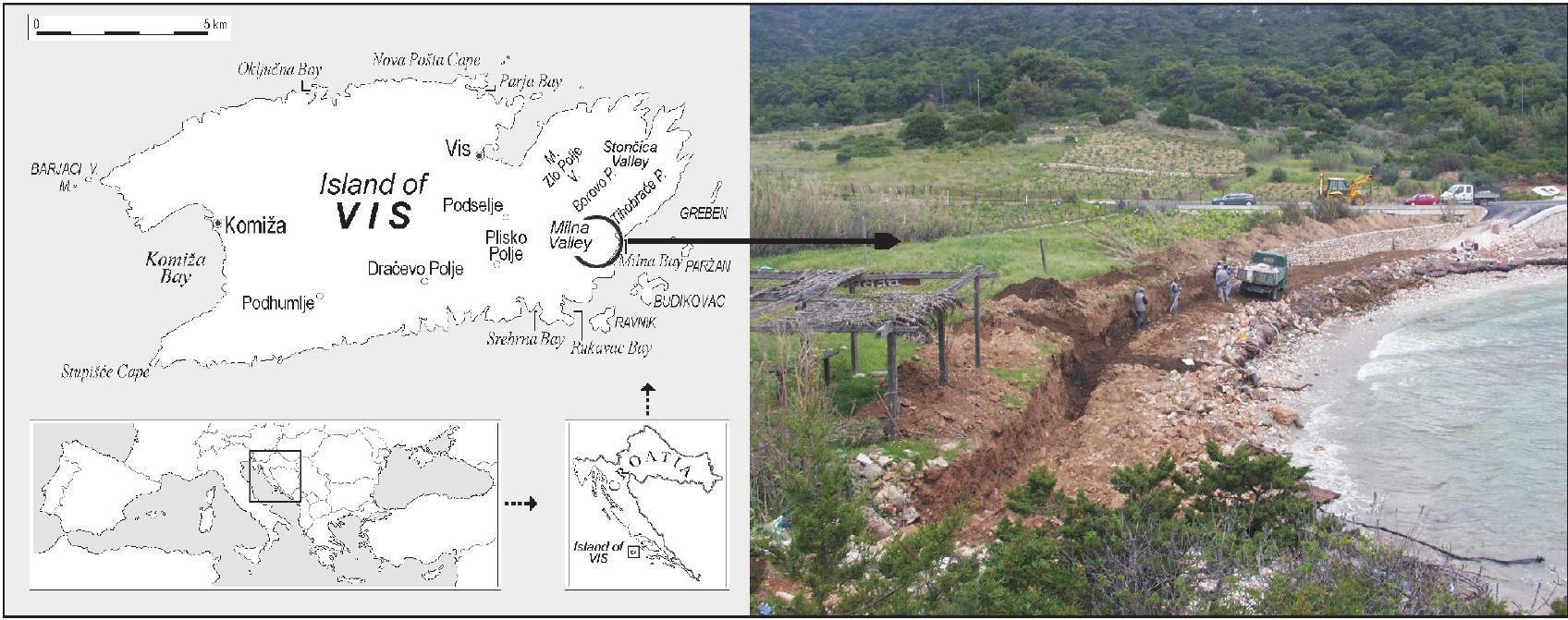




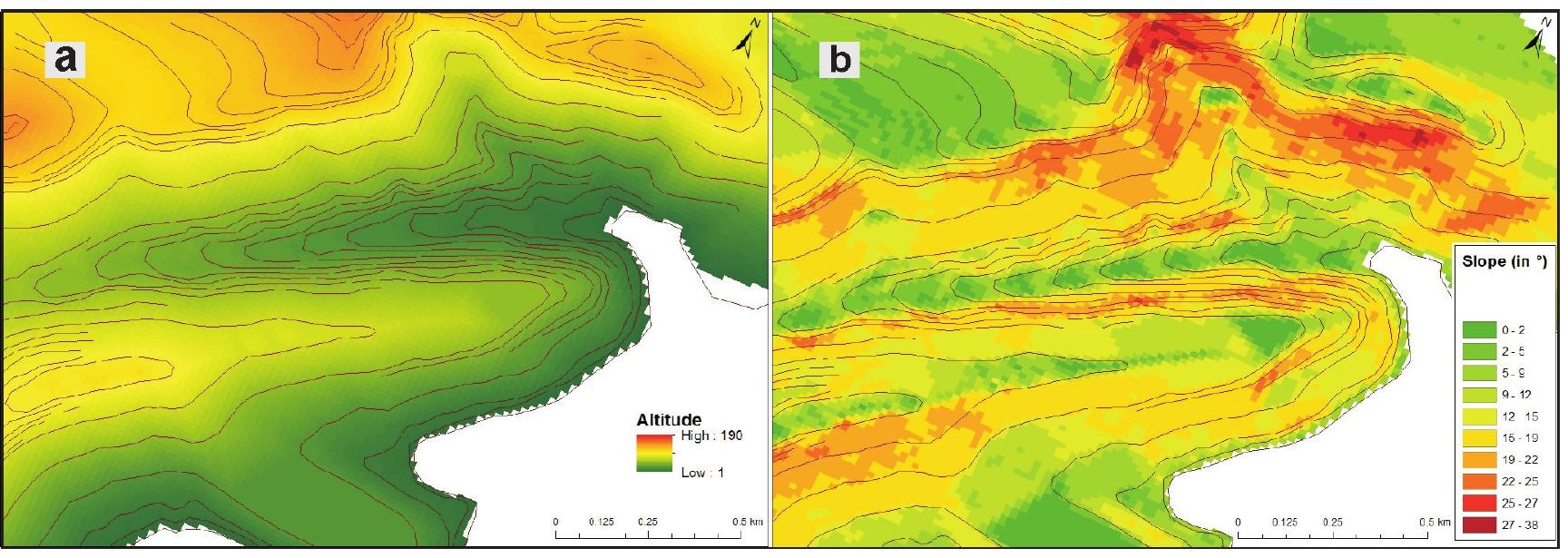




\section{a}

\section{b}

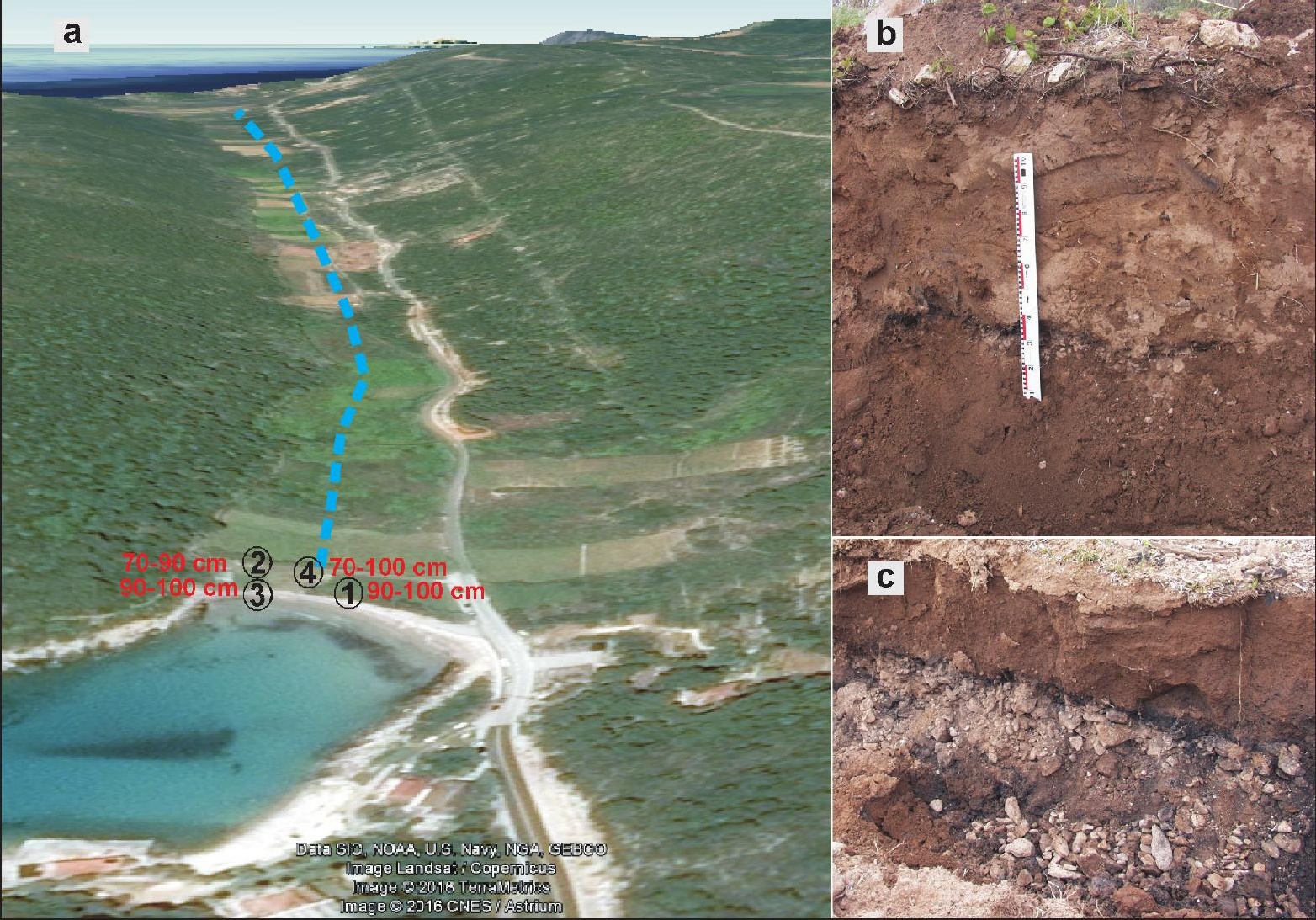


a

\section{0 pm}

c1

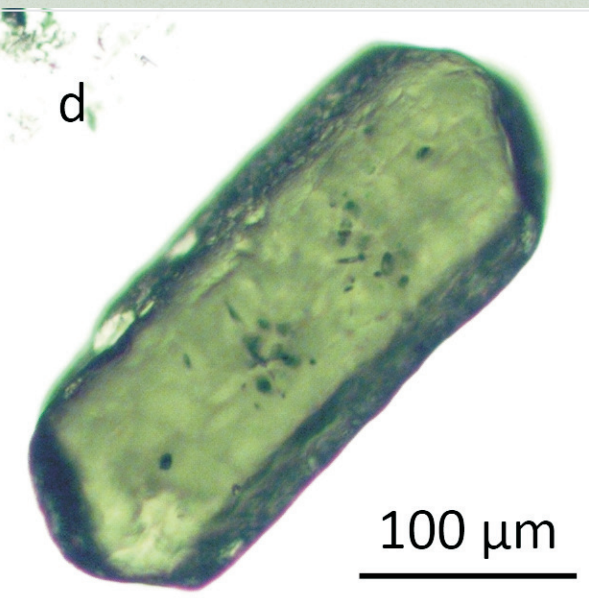

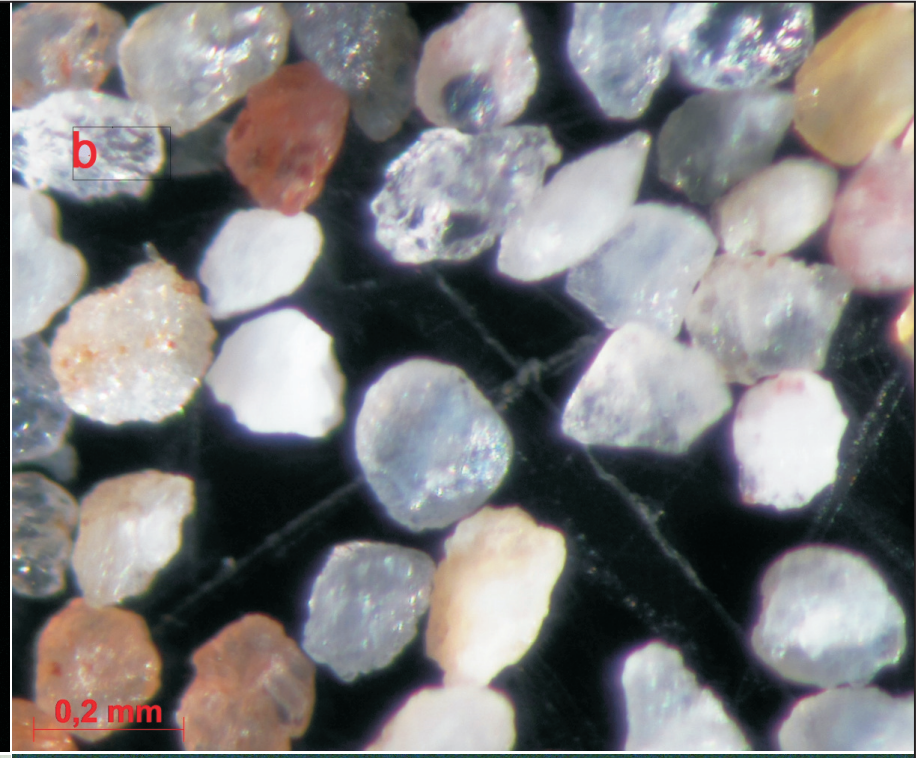

c2

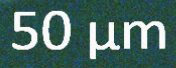

e

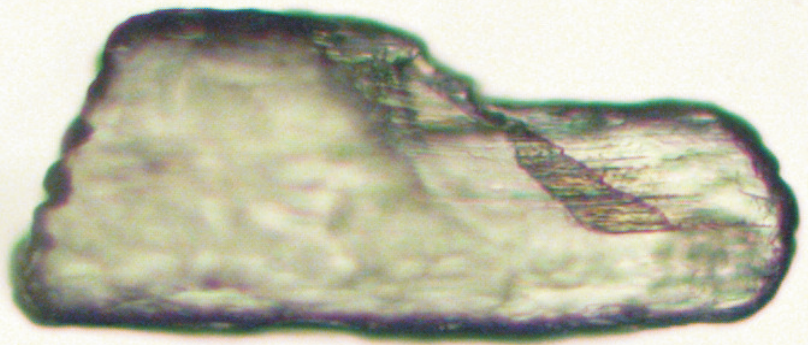

$100 \mu \mathrm{m}$ 

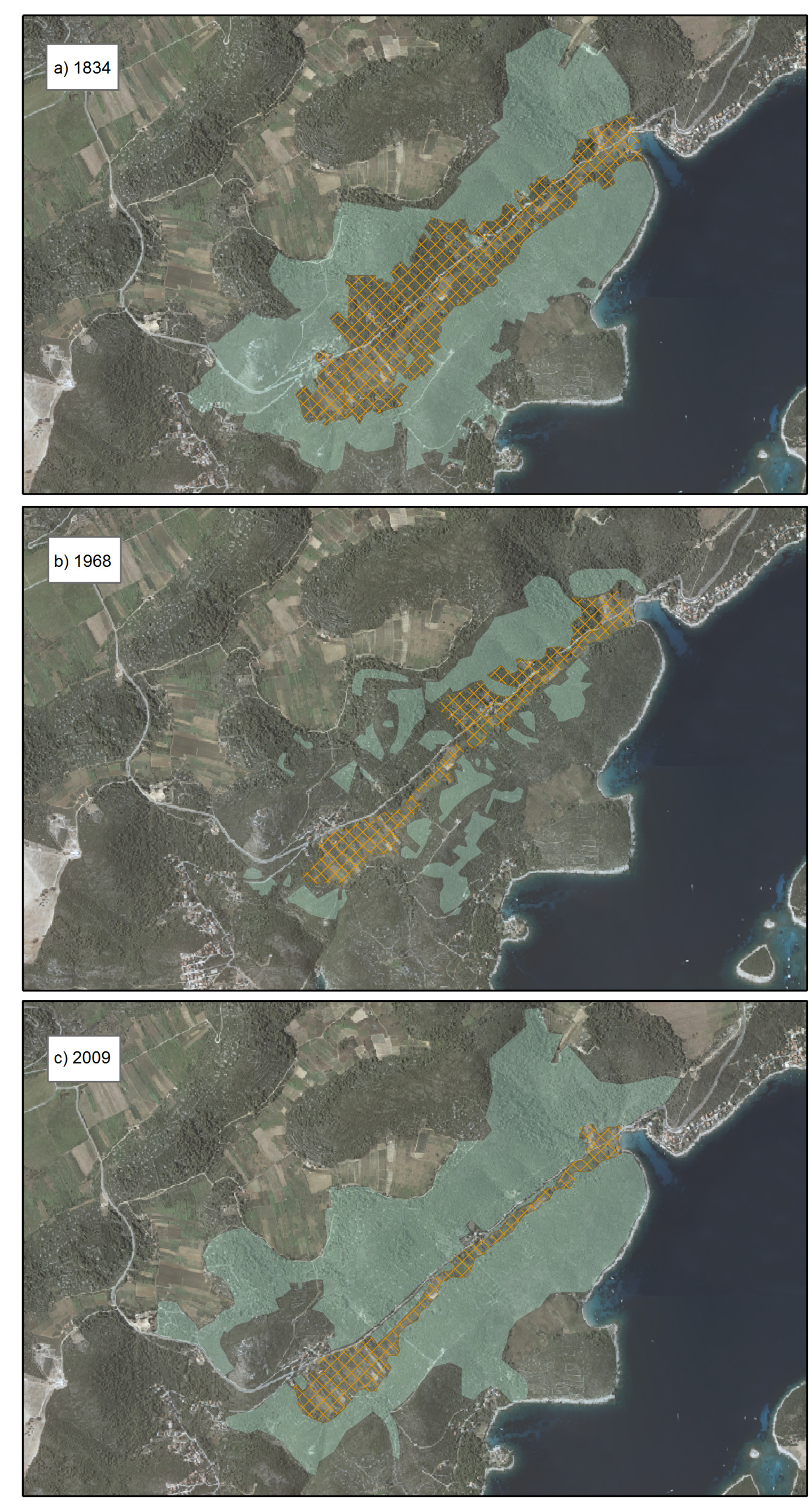

Natural vegetation

Agricultural land

0

0.5

$1 \mathrm{~km}$

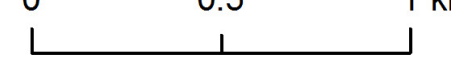




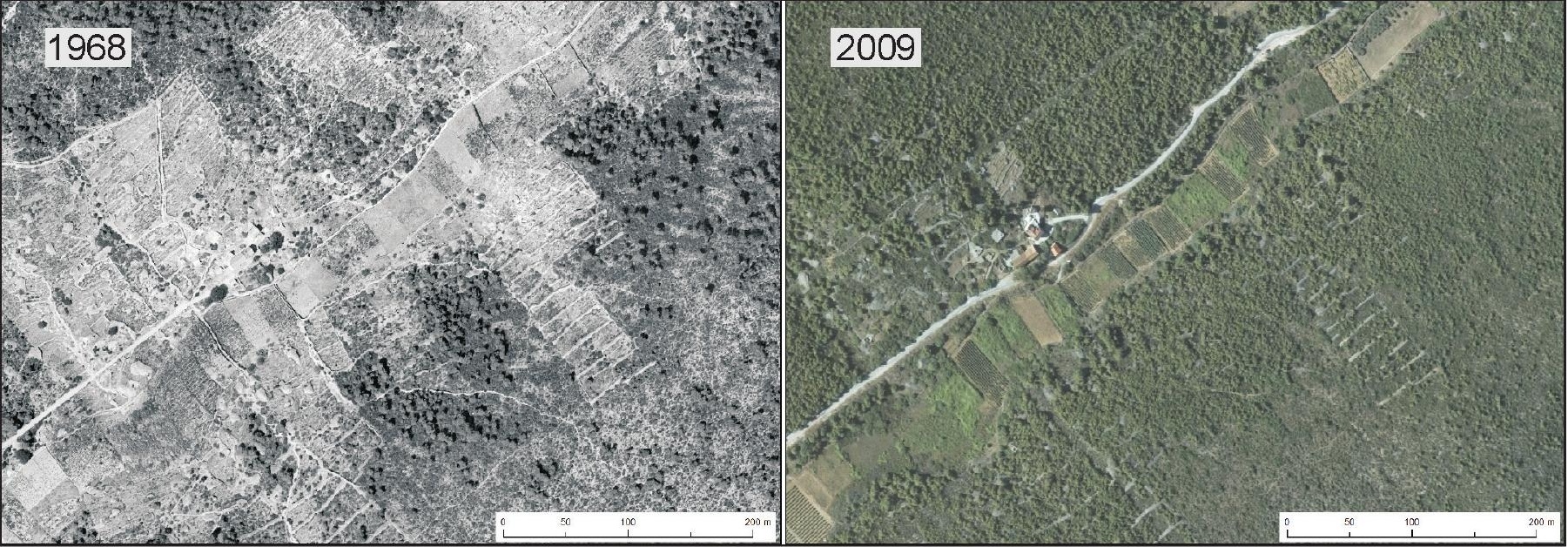




\section{Quaternary International}

We the undersigned declare that this manuscript is original, has not been published before and is not currently being considered for publication elsewhere.

We confirm that the manuscript has been read and approved by all named authors and that there are no other persons who satisfied the criteria for authorship but are not listed. We further confirm that the order of authors listed in the manuscript has been approved by all of us.

We understand that the Corresponding Author is the sole contact for the Editorial process. $\mathrm{He} / \mathrm{she}$ is responsible for communicating with the other authors about progress, submissions of revisions and final approval of proofs.

Signed by all authors as follows:

Sanja Faivre

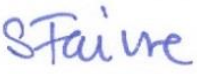

Lidija Galović,

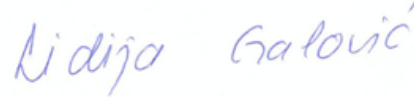

Pál Sümegi,

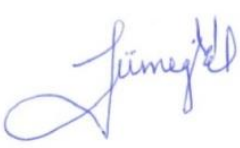

Marin Cvitanović,

$$
\text { mitand } M .
$$

Katalin Náfrádi and

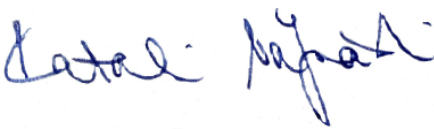

Nada Horvatinčić

$$
\text { Horvatinatc }
$$

